\title{
Telomere Length and Oxidative Stress and Its Relation with Metabolic Syndrome Components in the Aging
}

\author{
Graciela Gavia-García ${ }^{1}$, Juana Rosado-Pérez ${ }^{1}$, Taide Laurita Arista-Ugalde ${ }^{1}$, Itzen Aguiñiga-Sánchez ${ }^{2}$, \\ Edelmiro Santiago-Osorio $^{2}$ (D) and Víctor Manuel Mendoza-Núñez ${ }^{1, *(D)}$ \\ 1 Research Unit on Gerontology, FES Zaragoza, National Autonomous University of Mexico, \\ Mexico City 09230, Mexico; ggg1501@hotmail.com (G.G.-G.); \\ juanarosadoperez@comunidad.unam.mx (J.R.-P.); tdlarista@gmail.com (T.L.A.-U.) \\ 2 Hematopoiesis and Leukemia Laboratory, Research Unit on Cell Differentiation and Cancer, FES Zaragoza, \\ National Autonomous University of Mexico, Mexico City 09230, Mexico; \\ itzen.aguiniga@zaragoza.unam.mx (I.A.-S.); edelmiro@unam.mx (E.S.-O.) \\ * Correspondence: mendovic@unam.mx; Tel.: +52-55-5623-0721; Fax: +52-55-5773-6330
}

check for updates

Citation: Gavia-García, G.;

Rosado-Pérez, J.; Arista-Ugalde, T.L.; Aguiñiga-Sánchez, I.;

Santiago-Osorio, E.; Mendoza-Núñez, V.M. Telomere Length and Oxidative Stress and Its Relation with Metabolic Syndrome Components in the Aging. Biology 2021, 10, 253. https:// doi.org/10.3390/biology10040253

Academic Editor: Roberta Fusco

Received: 14 February 2021

Accepted: 19 March 2021

Published: 24 March 2021

Publisher's Note: MDPI stays neutral with regard to jurisdictional claims in published maps and institutional affiliations.

Copyright: (c) 2021 by the authors. Licensee MDPI, Basel, Switzerland. This article is an open access article distributed under the terms and conditions of the Creative Commons Attribution (CC BY) license (https:/ / creativecommons.org/licenses/by/ $4.0 /)$.
Simple Summary: A link between telomere length and some age-related diseases has been identified, including metabolic syndrome. So far, there is no mechanism to explain the origin or cause of telomere shortening in this syndrome; however, oxidative stress is a constant factor. Therefore, we reviewed scientific evidence that supported the association between oxidative stress and telomere length dynamics, also examining how each of the metabolic syndrome components individually affects the length. In this regard, there is strong scientific evidence that an increase in the number of metabolic syndrome components is associated with a shorter telomere length, oxidative damage at the lipid and DNA level, and inflammation, as well as its other components, such as obesity, hyperglycemia, and hypertension, while for dyslipidemia, there is a little more discrepancy. The difficulty for the correct treatment of metabolic syndrome lies in its multifactorial nature. Hence, there is a need to carry out more studies on healthy lifestyles during aging to prevent and reduce oxidative damage and telomere wear during aging, and consequently the progression of chronic degenerative diseases, thus improving the living conditions of older people.

Abstract: A great amount of scientific evidence supports that Oxidative Stress (OxS) can contribute to telomeric attrition and also plays an important role in the development of certain age-related diseases, among them the metabolic syndrome (MetS), which is characterised by clinical and biochemical alterations such as obesity, dyslipidaemia, arterial hypertension, hyperglycaemia, and insulin resistance, all of which are considered as risk factors for type 2 diabetes mellitus (T2DM) and cardiovascular diseases, which are associated in turn with an increase of OxS. In this sense, we review scientific evidence that supports the association between OxS with telomere length (TL) dynamics and the relationship with MetS components in aging. It was analysed whether each MetS component affects the telomere length separately or if they all affect it together. Likewise, this review provides a summary of the structure and function of telomeres and telomerase, the mechanisms of telomeric DNA repair, how telomere length may influence the fate of cells or be linked to inflammation and the development of age-related diseases, and finally, how the lifestyles can affect telomere length.

Keywords: metabolic syndrome; telomere; telomerase; oxidative stress; aging; lifestyles

\section{Introduction}

\subsection{Structure and Function of Telomeres}

Telomeres are DNA-protein complexes that are localised at the edge of chromosomes, with more than 2000 repetitions of the "TTAGGG" sequence of non-coding double-strand DNA and ending with a guanine rich single-stranded DNA [1,2]. Telomeres are necessary for the stability and protection of genomic DNA and prevention of chromosomal fusion [3]. 
In addition, they are involved in signaling pathways that regulate cell proliferation, thus establishing the lifespan of a cell $[4,5]$. Hence, telomeres are considered biological clocks that determine the number of divisions that a cell undergoes [6,7]. Telomeres are constituted by protein complexes such as the telosome or shelterin complex, CTC1-STN1-TEN1 (CST) complex, and associated proteins [8,9], whose general function is to guide the cell fate through dynamic structural and organisational transitions [10].

Shelterin is a protein complex consisting of six subunits: telomeric repeat-binding factor 1 (TRF1), telomeric repeat-binding factor 2 (TRF2), protection of telomeres protein 1 (POT1), repressor activator protein 1 (RAP1), TRF1-interacting nuclear factor 2 (TIN2), and adrenocortical dysplasia protein homolog (TPP1) [10]. Meanwhile, the CST complex is comprised of three proteins: conserved telomere protection component 1 (CTC1), suppressor of cdc thirteeN 1 (STN1), and telomeric pathway with STN1 (TEN1) [11]. Shelterin complex binds to the telomeres through TRF1 and TRF2. TRF1 is involved in the negative regulation of the telomeric length (TL), by inhibiting the telomerase activity [12-14]. On the other hand, TRF2 plays an important role in the cell cycle progression and the protection against the chromosome end-to-end fusion. Both proteins present three helixes that bind exclusively to the telomeric DNA through a Myb-type domain. The third helix of TRF1 recognises the TT sequence and binds to the DNA as a homodimer, preferably to doublestranded DNA; then, it binds with TIN2, which confers the capacity to interact with TPP1 and POT1. On the other hand, the TRF2 homodimer binds to double-stranded DNA and then, similar to TRF1, it binds to TIN2 [14-16].

POT1 interacts directly with the single-stranded DNA and can tangle with TPP1. This protein plays different roles including avoiding segregation defects, chromosomic instability, loss of telomeric sequences, chromosome end-to-end fusion, and unwanted repairing activities [17-19]. Regarding the RAP1 subunit, it is known that this protein is characterised for its dual function, as it participates in the control of gene expression, as well as in chromosome maintenance [20]. In addition, it can interconnect with TRF2 [21].

TIN2 is another important protein of the shelterin complex that binds simultaneously to POT1/TPP1 and TRF1/TRF2, and it avoids the wrong identification of damage in the telomeric DNA $[21,22]$ and, similar to TRF1, it can act as a negative regulator of the TL $[4,14]$. The TPP1 protein can assemble with the telomeres through POT1 and TIN2 [23,24], and it also takes part as a recruitment factor for the telomerase enzyme through a region known as the strictly conserved surface of TPP1 OB (TEL patch) [25] as well as in the stimulation of the enzyme progression [26].

The synthesis of the complementary chain through the DNA polymerase $\alpha$ is necessary to achieve telomere homeostasis [27]. However, this enzyme is not able to perform this function without the participation of the single-strand DNA binding complex CST. This protein complex promotes the duplex replication of the telomeres; that is why its elimination leads to dysfunction, instability, and telomeric frailty [28,29]. The interaction of the proteins CTC1 and STN1 limits the action of the telomerase to prevent the overextension of the guanine rich single-stranded DNA overhang; hence, it is considered as a regulatory step that limits telomere elongation [30,31]. On the other hand, TEN1 is a crucial protein for the synthesis of the complementary chain, since its absence triggers alterations in the replication restart; likewise, it participates in the telomere maintenance and protection and is a negative regulator of the telomerase enzyme (Figure 1) [31-33]. Finally, without the protective activity of each of these complexes, the DNA damage repair mechanisms could wrongly process the edge of the chromosomes [34]. 


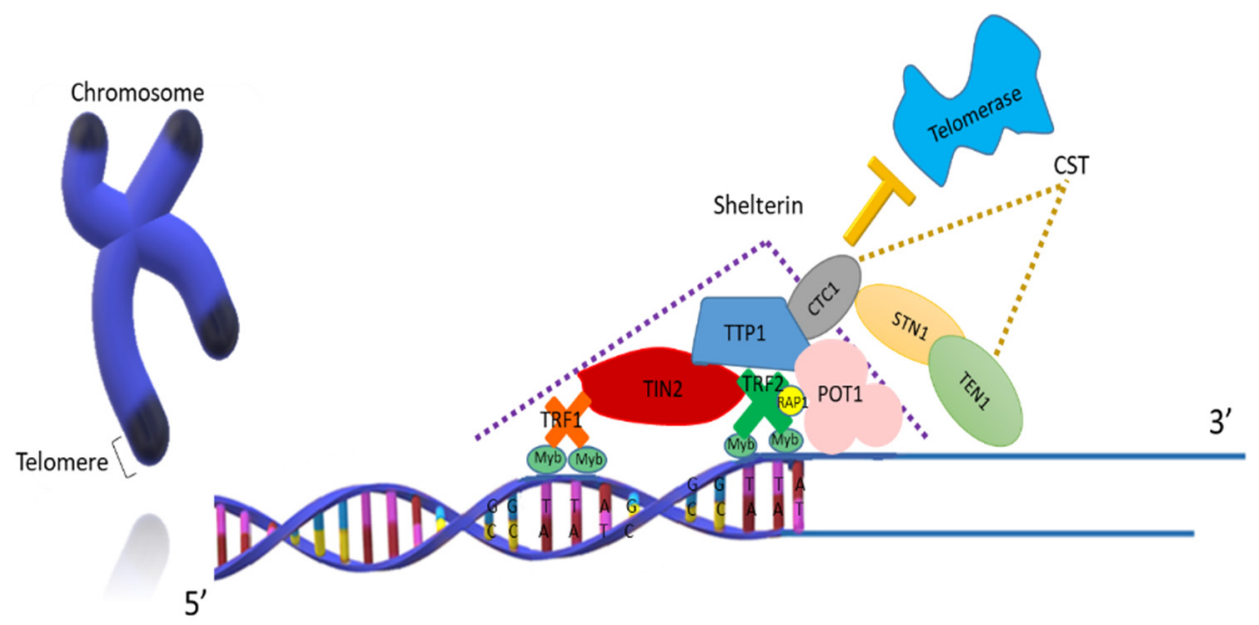

Figure 1. Structure of the shelterin and CTC1-STN1-TEN1 (CST) complexes. The shelterin complex is made up of the proteins telomeric repeat-binding factor 1 (TRF1), telomeric repeat-binding factor 2 (TRF2), TRF1-interacting nuclear factor 2 (TIN2), adrenocortical dysplasia protein homolog (TPP1), protection of telomeres protein 1 (POT1), and repressor activator protein 1 (RAP1). TRF1 and TRF2 subunits bind to the double-stranded telomeric DNA using Myb-type domains and the POT-1 subunit binds to the single-stranded. On the other hand, the CST complex made up of the proteins CTC1, STN1, and TEN1 inhibits the activity of the telomerase enzyme.

\subsection{Telomerase Structure and Function}

Every time a cell divides, about 25-200 bp of the telomeric sequence is lost, which is a phenomenon that is also known as "the end-replication problem" where DNA polymerase cannot complete the terminal space of the double helix $[35,36]$. Hence, with the purpose of properly making the replication happen, the telomerase enzyme is required, which is a ribonucleoprotein that helps in the maintenance of the telomere length, in the $3^{\prime}-\mathrm{OH}$ chromosome end, through the transport and addition of tandem repeat RNA templates [37]. It has been established that when the telomeres are long enough, the presence of telomerase is not required, being necessary only when the TL falls within a critical range [38]. The human telomerase is constituted of two subunits that work simultaneously: the human telomerase RNA (hTERC, hTR, or TER) and the human telomerase catalytic subunit (hTERT) [39]. hTERC is an RNA molecule that is necessary for the stability and processing of the $3^{\prime}$ of the DNA; it contains a short complementary template of the telomeric DNA sequence [40]. hTERT has a reverse transcriptase activity and is responsible for adding the new segment without altering the phenotypic and morphogenic characteristics of the cell [41]. Subsequently, telomerase uncouples, and the DNA polymerase begins the synthesis of the complementary fragment of the $5^{\prime}$ end, avoiding then the telomeric shortening that comes with every cell division [42].

It is to notice that other accessory proteins are required for the telomerase to be fully functional, including dyskerin pseudouridine synthase 1 (DKC1), which is involved in telomere maintenance, ribosomal RNA biosynthesis, and pseudouridylation [43], and the telomerase Cajal body protein 1 (TCAB1), which is capable of associating with the telomerase and directly moving it towards the telomere. It is known that a TCAB1 depletion impedes hTERC from binding to Cajal bodies (nuclear regions that participate in the organisation of the genome, genic expression and RNA splicing fidelity) [44-46]. Some proteins are located in the Cajal bodies and can interact with the hTERC subunit [47] denominated: H/ACA ribonucleoprotein complex subunit 1 (GAR1), H/ACA ribonucleoprotein complex subunit 2 (NHP2), and H/ACA ribonucleoprotein subunit 3 (NOP10), considered key biomolecules of the small nucleolar RNAs (snoRNAs); thus, these proteins participate in post-transcriptional mechanisms such as methylation and ribosomic RNA modifications [48]. It has been observed that patients that present mutations in NHP2 or 
NOP10 present low levels of hTERC subunit in peripheral blood, which leads to alterations in the telomere [49].

Other proteins that play an essential role in the assembly or remodeling of the telomerase are ATPases pontin and reptin (Figure 2) [50,51]. Both proteins participate in telomerase biogenesis, particularly in the $S$ phase of the cell cycle. The reptin/pontin/TERT complex is considered an immature complex, also known as pre-telomerase with low catalytic activity, which can subsequently rearrange to form the mature TERC/TERT/DKC1 complex with a high catalytic activity [52].

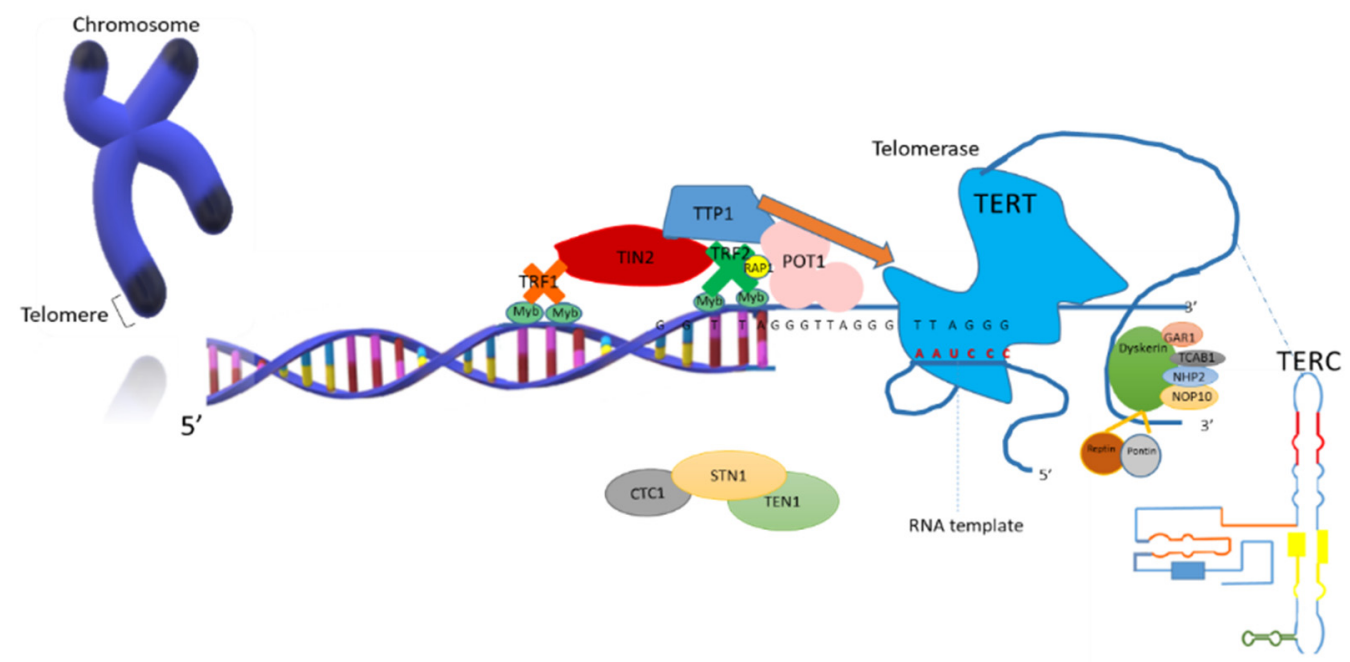

Figure 2. Scheme of the telomerase complex, consisting of two main subunits: telomerase RNA (TERC) that contains the RNA template region, and telomerase catalytic subunit (TERT), which is responsible for adding the new segment. Adrenocortical dysplasia protein homolog (TPP1) acts as a telomerase recruiter. In addition, the accessory proteins for the enzyme to be fully functional are shown: Dyskerin, H/ACA ribonucleoprotein complex subunit 1 (GAR1), telomerase Cajal body protein 1 (TCAB1), H/ACA ribonucleoprotein complex subunit 2 (NHP2), and and H/ACA ribonucleoprotein subunit 3 (NOP10). The pontin and reptin proteins are in charge of its remodeling and assembly.

The activity of the telomerase enzyme is limited in most somatic cells, causing the telomeres to shorten, which finally leads to replicative senescence (an irreversible arrest of the cell cycle). However, the activity of this enzyme can be reactivated in between 80 and $90 \%$ of the distinct types of cancer. There is no evidence of another broadly expressed gene among all known cancers $[38,53,54]$. In addition, $5-10 \%$ of the tumors use a molecular mechanism denominated the alternative lengthening of telomeres (ALT) that provides the capacity of maintaining the telomere length even without telomerase $[54,55]$. The carcinogenic transformation also seems to depend on certain types of responses such as oncogenic activation or tumor suppressors inactivation such as p53 [41]. Similarly, the elongation of the TL is related to the immortal cell phenotype, which is considered as a hallmark of neoplasic cells [56]. Thus, the activity of this enzyme can be used as a key diagnostic tool for cancer, while its inhibitors could be used as antitumoral agents [6,57].

On the other hand, researchers have determined an association between the levels and/or the activity of the telomerase and metabolic disorders such as type 2 diabetes mellitus (T2DM), hypertension, dyslipidemia, and psychological stress [58,59]. For example, in animal models, it has been identified that a lower telomerase activity caused by a TERC subunit deficiency affects the capacity of replication of $\beta$-pancreatic cells, causing alterations in insulin secretion and glucose intolerance [58]. Conversely, it has been suggested that non-controlled hypertension is associated with high telomerase activity in leukocytes [60]. Based on the above, it can be proposed that metabolic disorders are key factors that can trigger the dynamics of telomerase activity behavior. In addition, it is 
important to highlight that many metabolic disorders are associated with changes in TL in aging [61].

\section{Telomeric Length and Cell Fate in Aging}

Normally, when telomeres reach a critically short length in one or more chromosomes, they no longer have the capacity to safeguard the genome integrity [62]. For example, it is estimated that the minimal number of repetitions for the correct maintenance of the telomere must $\geq 500 \mathrm{bp}$ [63], and at least 12.8 TTAGGG repetitions prevent chromosomes from end-to-end fusion [64]. This leads the cell to limit the proliferation through processes such as senescence, which is a mechanism that permanently blocks cell division, and apoptosis (programmed cell death) $[57,65,66]$.

During aging, there is a major drawback when TL is shortened, as organ regeneration capacity is limited with possible modifications in gene expression even before the onset of senescence or apoptosis $[67,68]$. Senescent cells are generally eliminated from the tissue by the immune system. However, the impaired immune system of aged individuals fails to clear all the senescent cells; thus, the ones that remain in the tissue are non-functional cells that can jeopardise the tissue architecture and function [7]. In other words, senescent cells are accumulated through aging and in some cases promote the appearance of cancer in the tissue [68-72].

The above can be attributed to the fact that senescent cells are metabolically active and can influence the surrounding cells through the secretion of growth factors, cytokines, chemokines, and matrix-remodeling enzymes, also known as Senescence-Associated Secretory Phenotype (SASP), which can be associated with the structural and functional decay of the tissue, also triggering tumorigenesis [71].

There are new encouraging strategies to attenuate health decline at older ages or to delay aging. One of them is through the elimination of senescent cells by compounds called senolytics or by senomorphic compounds that inhibit or attenuate the SASP $[73,74]$. The research on such molecules has been growing in recent years, and therefore, the association between senolytics and senomorphics with other age-related diseases has come to light. Regarding the latter, it has been observed that the acute administration of lithium carbonate is able to reduce the SASP of human astrocyte-derived induced pluripotent stem cells (iPSCs) [75]. In addition to the above, the administration of this compound is also involved in telomere length dynamics, since chronic treatment in a triple transgenic experimental model of Alzheimer's disease increases TL in the hippocampus and parietal cortex in a tissue-specific manner [76]. Furthermore, its long-term use is associated with longer TL in peripheral blood leukocytes from bipolar patients [77]. Therefore, pharmacological targeting of these compounds could transform geriatric medicine by preventing or delaying telomeric attrition and/or the onset of metabolic diseases such as metabolic syndrome (MetS), where senescence could be contributing by increasing systemic inflammation and insulin resistance in T2DM [74,78-81]. Although the effect of senolytics has been proven, we should not lose sight of the fact that senescence also participates in beneficial processes for health, such as tissue repair and protection against the development of carcinogenic processes, among others [82].

Telomeres do not trigger apoptosis by themselves, but the absence of the protein TRF2 in the shelterin complex does trigger this process because the DNA without a telomere is identified as damaged, which is a process regulated by proteins such as p53 and the kinase Ataxia Telangiectasia Mutated (ATM) [83,84].

Telomeric shortening is not exclusive of somatic cells; it can also occur in gametic cells. For example, in human oocytes, telomere shortening leads to apoptosis in embryonic cells [85], being more frequent in aged women, with the possibility of miscarriage, birth defects, and infertility [86]. On the other hand, TL shortening in spermatocytes is evident in men with a low concentration of spermatocytes (oligozoospermia) that is directly associated with the age of the parents at the moment of conception [87], which predispose to apoptosis in spermatic cells [88] and male infertility [89]. 


\section{Reactive Oxygen Species and Antioxidants}

The mitochondrion plays a crucial role for cell survival, as it is involved in ATP production by electron transport enzyme complexes in the respiratory chain, in which reactive oxygen species (ROS), such as superoxide radical $\left(\mathrm{O}_{2}{ }^{\bullet-}\right)$ are invariably produced by electron transfer to molecular oxygen. This happens particularly in complexes I (Nicotine adenine dinucleotide reduced (NADH) ubiquinone oxidoreductase) and III (ubiquinolcytochrome c oxidoreductase) of the mitochondrial inner membrane [90].

Under physiological conditions, ROS act as second messengers that participate in several signaling pathways to maintain the homeostasis, growth, and normal development of aerobic organisms [91,92]. However, Oxidative Stress (OxS) occurs when there is an imbalance of oxidants (such as ROS) and antioxidant mechanisms, where the presence of the first is in a higher proportion $[93,94]$. As mentioned earlier, $\mathrm{ROS}$ such as the $\mathrm{O}_{2}{ }^{\bullet-}$ are generated by the electron transport chain and, in the presence of transition metals such as $\mathrm{Fe}^{3+}$, transforms into hydrogen peroxide $\left(\mathrm{H}_{2} \mathrm{O}_{2}\right)$, which together with $\mathrm{O}_{2}{ }^{\bullet-}$ becomes hydroxyl radical $\left({ }^{\bullet} \mathrm{OH}\right)$ through Fenton and Haber-Weiss reactions [95]. Hydroxyl radical and oxygen singlet $\left({ }^{1} \mathrm{O}_{2}\right)$ can generate DNA adducts, such as thymine glycol or 8-hydroxy$2^{\prime}$-deoxyguanosine (8-OHdG). The last one results from the binding of the ${ }^{\bullet} \mathrm{OH}$ to the eighth carbon of the guanine [96]. 8-OHdG transforms into its oxidised form 8-oxo-7,8dihydro-2'-deoxyguanosine (8-oxodG) through a keto-enol tautomerism reaction, which is considered the most abundant oxidative injury, with about 100,000 8-oxodG generated every day in a single cell $[97,98]$.

Despite all the damage that elevated ROS levels may induce, the organisms are endowed with antioxidant defense mechanisms, which are synthesised de novo (endogenous) or acquired through the diet (exogenous). These systems are capable of counteracting or eliminating directly or indirectly the ROS and/or its derivatives, such as reactive nitrogen species (RNS) or reactive sulfur species, to maintain redox homeostasis $[99,100]$. For example, $\mathrm{O}_{2}{ }^{-}$can be rapidly transformed by the enzyme superoxide dismutase (SOD) into $\mathrm{H}_{2} \mathrm{O}_{2}$, which is converted into less toxic products by the enzyme catalase (CAT) or glutathione peroxidase (GPx) [90]. However, oxidative damage increases gradually over time because antioxidant defense mechanisms decline with age [101]. It has been proposed that OxS theory is a direct cause for aging, which is based on the molecular disorder generated by the free radical accumulation [102]; this disorder may cause oxidative damage in several biomolecules and alterations in redox homeostasis, resulting in the appearance of age-related diseases [103-106].

Likewise, OxS can influence cellular fate, since it has been proposed that ROS are triggers of senescence and apoptosis. For example, it has been observed that fibroblasts treated with low concentrations of $\mathrm{H}_{2} \mathrm{O}_{2}$ become senescent, while treatment with a high concentration leads to apoptosis [107]. Other in vitro studies have revealed that cells with a normal TL and telomerase expression show greater resistance against apoptosis compared to cells from older organisms [108]. Thus, higher concentrations of ROS upregulate the signaling pathways associated with cell death $[109,110]$.

\section{Telomere Shortening and Oxidative Stress}

Due to the high content of guanines in the telomeric region, it is susceptible to oxidative damage. Thus, the adduct can be found in this region at a higher proportion, even seven times more, compared to genomic DNA [111,112]. The molecule 8-oxodG is considered as a pre-mutagenic lesion that is capable of inadequately binding to adenine, leading to transversions GC-TA, which subsequently generates several alterations such as single-strand brakes, inadequate replication of the telomeric DNA, accelerated telomere shortening [113], and if the DNA damage repair mechanisms fail, it can lead to cellular physiology modifications, senescence, or apoptosis [91].

It has been postulated that even without oxidative damage, the telomeres would shorten with every mitotic cycle, and the aging process would happen inevitably. However, 
during the aging process, $\mathrm{OxS}$ is a major factor that significantly contributes to the telomere shortening rate [114,115].

In addition, it has been proposed that the oxidative damage induced by ROS induces a tissue-specific reduction of the TL, which is derived from the antioxidant capacity of each tissue $[116,117]$. The damage generated by OxS can interfere with the assembly of the telomere maintenance proteins such as TRF1, TRF2, and POT1 with the DNA; even a single 8-oxodG lesion can induce a $50 \%$ reduction in the levels of such proteins, leading to telomeric instability [118]. Meanwhile, it has been observed that senescent cells' 8-oxodG levels are $35 \%$ higher compared to control cells by inducing cell growth arrest [119].

Another event linking OxS and rapid telomere attrition is given by the loss of the enzyme peroxiredoxin-1 (PRDX1), where the DNA damage sensor-dependent repair involved in the base excision repair (BER) mechanism, known as poly(ADP-ribose)-polymerase-1 (PARP1), is inefficient [120]. This condition causes the accumulation of telomeric singlestrand DNA breaks (SSBs), which in turn become potentially lethal telomeric double-strand breaks (DSBs) [121]. DSBs are repaired by the high-fidelity template-dependent homologous recombination (HR) repair pathway or error-prone non-homologous end joining (NHEJ) [122]. For example, alterations in HR repair generated by the inhibition of PARP1 activity cause SSBs to persist, leading to genomic catastrophe and telomeric shortening, and ultimately apoptosis $[120,123]$.

\section{Telomere Length and Age-Related Diseases and Oxidative Stress}

Aging is defined as a gradual and adaptive process that is characterised by a decline in the biological response to maintain or recover homeostasis against the challenges that a person faces during the lifespan in a given environment [124]. It is estimated that in 2050 , the percentage of people over 60 years may reach $22 \%$. This means that in the world, there will be around 2000 million people belonging to this age group [125]. That is why it is necessary to count on opportune interventions that allow elderly people to contribute to social development and prevent them from turning into a crisis factor for healthcare structure [126].

It is well accepted that telomeres help stabilise the nuclear genome with high fidelity, but this function declines with age in the post-reproductive stage [1]. The loss of telomeric repetitions as well as the enzymatic activity of the telomerase are dynamic processes that regulate differentially during each stage of life $[6,56]$. Thus, short telomere length is a biomarker of aging that incites the cell to develop certain diseases, limiting with it the overall health status of a person [127]. Several studies support the association between a short telomere with age-related diseases and their complications, such as T2DM, cardiovascular diseases, myocardial infarction, cataractogenesis, osteoporosis, MetS, neurodegenerative diseases such as Alzheimer's disease, and sleep disorders; as well as dementia, cognitive decline and premature mortality (Figure 3) [127-135]. In that same order, researchers have identified gene variations in human leukocytes, specifically a single nucleotide polymorphism (SNP) rs3772190 in the TERC locus, which is associated with a short TL and longevity [136]. It has been suggested that antioxidants could reduce the telomere shortening rate during aging, but when it comes to transformed cells, the effect may not be wanted $[2,137]$. To date, there has been no other inherent mechanism that explains the origin and/or causes of the telomere shortening in these pathologies. However, OxS seems to be constant [138]. 


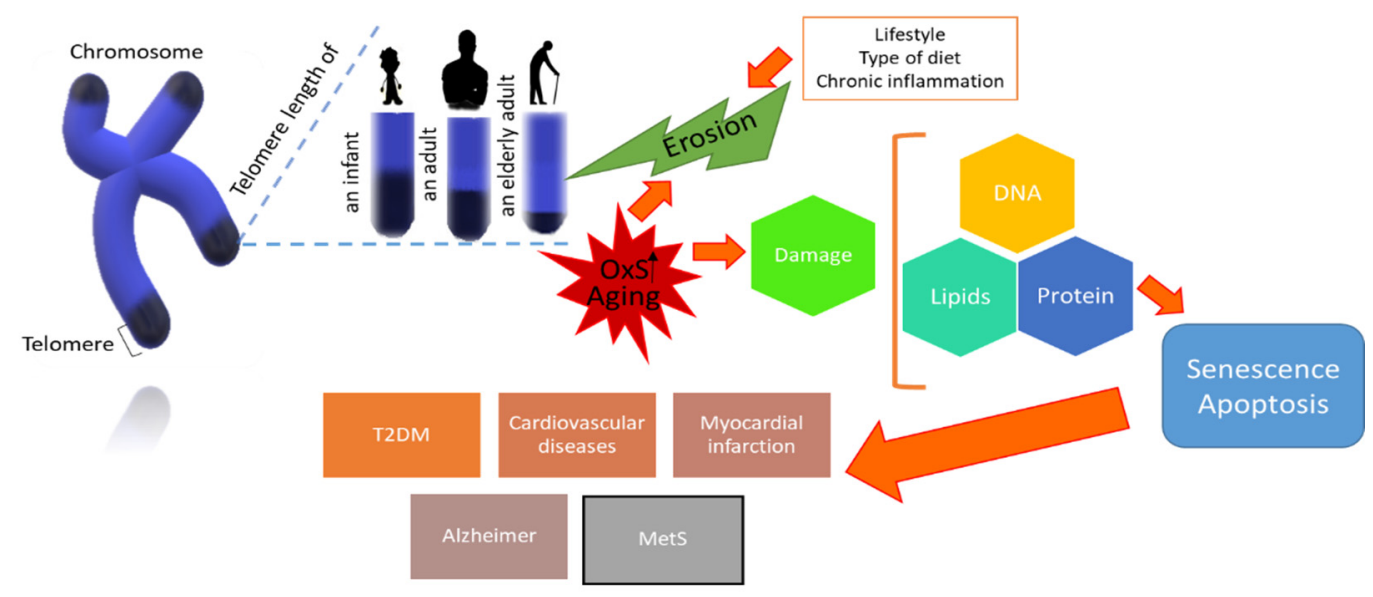

Figure 3. Telomere attrition in aging. OxS and other factors such as lifestyle can cause damage to biomolecules, apoptosis, or senescence, which manifests itself with the appearance of age-related diseases, among them the MetS. OxS: Oxidative Stress; MetS: Metabolic Syndrome.

There is evidence that points out that besides age, there are other factors related to telomere attrition, among them the lifestyle, diet, as well as environmental and social response to which the individual is subjected [134,139], and at a cellular level, chronic inflammation and oxidative damage $[140,141]$, which may compromise the immune system functions [142,143]. As for OxS, it should be noted that it is associated with short telomeres in aging, which have been found in recent studies in people over 65 years old with high iron levels [144] and sarcopenia [145]. Likewise, it has been observed an increase in lipoperoxidation $[146,147]$ is associated with a higher risk of death [148], a decay in the overall antioxidant state, and the activity of the GPx in erythrocytes from healthy people $>60$ years old compared to young adults. Therefore, these findings suggest that an advanced age predisposes to an increase in OxS [147].

\section{Damage Repair of the Telomeric DNA}

The habitual genomic DNA damage repair mechanisms must be modified or suppressed in the telomeric regions in order not to be recognised and processed as DSBs [55]. Telomeric DNA repair is known to be not as efficient as in other chromosomal areas, since there is evidence that shows that the genome of human cells put through OxS is repaired in the first $24 \mathrm{~h}$, while the telomeric regions can remain unrepaired for up to 19 days [149]. Similarly, telomeric DNA repair is less efficient in aged cells, where it possibly has an impact on genome stability [150]. On the other hand, it has been proposed that cell senescence originates as a consequence of irreparable damage to telomeric DNA [151].

Telomeric DNA can be repaired by BER and to a lesser extent by nucleotide excision repair (NER) and mismatch repair (MMR) [152]. In general, it is speculated that BER repairs the small lesions in the DNA; on the contrary, NER eliminates the bigger ones [153]. Likewise, some products generated by oxidation, such as 8-oxodG, are identified by BER, while the $5^{\prime} 8$-cyclopurines are recognised by NER [154]. Surprisingly, the proteins shelterin, TRF1, TRF2, and POT1 help in the repair process by increasing the speed of individual steps of the BER long-patch repair and with that protecting the telomeric DNA from degradation [155].

Oxidative damage in the DNA is repaired mainly by the enzyme 8-oxoguanosine DNA glycosylase-1 (OGG1), which is a glycosylase that has the capacity of excising directly the 8-oxodG lesion from the nuclear or mitochondrial DNA [156]. It is known that some telomeric structures such as $3^{\prime}$-overhang, D-Loop, and fork-opening are eliminated with lower efficiency by the OGG1 [157]. A decrease in the expression of OGG1 may lead to the accumulation of oxidant lesions associated with tumoral phenotypes [158,159].

Hence, a malfunction in the repair mechanisms is associated with accelerated aging and chromosome instability, which predisposes to mutagenesis, carcinogenesis, or mor- 
phological nuclear abnormalities such as nuclear buds, micronucleus, and nucleoplasmic bridges [160].

Likewise, new evidence indicates that telomeric dysfunction causes the transcription of telomeric non-coding RNAs (tncRNAs) that in turn control the DNA damage response (DDR) [161]. This transcription gives rise to a type of long noncoding RNAs (lncRNA) known as TERRA (Telomeric repeat-containing RNA) that are involved in the maintenance and processing of unprotected telomeres, chromosomal end heterochromatin formation, and telomerase activity [162-165]. Inhibition of tncRNAs by sequence-specific telomeric antisense oligonucleotides (tASOs) has been observed to prevent DDR activation [166] and cellular senescence both in vivo and in vitro, thereby improving homeostasis in fibroblasts from patients with Hutchinson-Gilford progeria syndrome (HGPS), which is characterised by premature aging and extending lifespan in an HGPS transgenic mouse model [161]. Similar to senolytics and senomorphics, inhibiting these ncRNAs with tASOs may be a promising step to prevent telomeric dysfunction, improve age-related diseases, and have a translational impact on MetS.

\section{Relationship of Oxidative Stress with the Metabolic Syndrome and Telomeric Length}

Advanced age is a risk factor for diseases that generally develop in a chronic and overlapping way-that is, they are long-lasting and associated with each other [167]. Among them is the MetS [168], whose prevalence among the youth from 20 to 29 is less than $10 \%$; while in adults aged 60 and over, it increases by $50 \%[169,170]$.

MetS is defined as a set of biochemical and clinical alterations characterised by obesity, dyslipidemia, arterial hypertension, insulin resistance, and hyperglycemia, presenting a prothrombotic and pro-inflammatory state [171]. This syndrome is a risk factor for cognitive decline, dementia, frailty, T2DM, and cardiovascular diseases, whose pathophysiology is associated with an increase in OxS [172,173].

In the same vein, it is assumed that both aging and MetS generate OxS, but the impact of the syndrome on this imbalance is much more significant than the produced by age, since the pro-oxidant state is manifested in each of its components, predisposing to metabolic and cardiovascular complications and organ damage, especially in the elderly [174-176]. A positive association between MetS components and OxS levels has been reported by cumulative effects; that is, a greater presence of components leads to higher levels of OxS [177]. Currently, it is under discussion whether OxS is the cause or consequence of MetS; however, it is hypothesised that both may be true [178].

In patients with MetS, there are alterations in the antioxidant protection mechanisms and in the inflammatory process; for example, high concentrations of $\mathrm{H}_{2} \mathrm{O}_{2}$ decreased the gene expression of SOD and increased the levels of interleukin 1 beta (IL1 $\beta$ ) in peripheral blood mononuclear cells (PBMCs) [179]. Similarly, an increase in transition metals such as iron or copper can generate OxS and exacerbate it, since high concentrations of these metals in serum [180,181] are associated with obesity [182], hypertriglyceridemia, low highdensity lipoprotein-cholesterol (HDL-C) levels [183], hypertension [184], blood glucose, and increased predisposition to T2DM [185].

Likewise, the presence of this syndrome predisposes to an increase in free radicals (FR), which are accepted as underlying mechanisms for mitochondrial dysfunction and an accumulation of oxidation products at the level of DNA (8-oxodG), lipids (prostaglandin F2 alpha (PGF2 $\alpha$ ), malondialdehyde (MDA) and 4-hydroxynonenal (HNE) [186-188], carbonylated proteins (PCO) [189], low-density lipoproteins (LDL) [190], and carbohydrates (glyoxal and methylglyoxal) $[174,191]$, which are associated with a decrease in antioxidant defense mechanisms due to low levels of vitamins C, E, and carotenoids [192-194], reduced glutathione (GSH) [195] and the enzymatic activity of SOD, GPx [196], and CAT [189]. This redox imbalance leads to an increased risk of metabolic complications $[197,198]$ and acceleration of telomeric attrition in the pathogenesis of MetS [199] (Table 1). The consequences of MetS at the telomere length level can be so serious that it can even affect the offspring, since the children of mothers with MetS may have shorter telomeres [200], 
which predisposes to a greater risk of presenting some chronic non-communicable diseases and mortality [201].

On the other hand, MetS has been positively associated with an increase in telomerase levels and activity $[189,202]$ and inversely with oxidised low-density lipoprotein (Ox-LDL), which leads to senescence and risk of chronic diseases such as atherosclerosis $[190,203]$ or, in the worst scenario, to the development of malignant tumors [204], since this condition is associated with a higher risk of colorectal cancer, as well as salivary glands and mortality from breast cancer in women $[205,206]$. In addition, in men, there is an increased risk of pancreatic cancer and Hodgkin's lymphoma of the thyroid [206]. Hence, the increasingly apparent link between MetS and cancer.

Similarly, there is information linking MetS components or OxS to telomere length in in vivo and in vitro models. For example, in a chimeric mouse model in which $100 \%$ of its cells were derived from embryonic cells with longer telomeres than normal (hyperlong telomeres) and lower levels of LDL and cholesterol, better tolerance to glucose and insulin were observed, and they are evidently thinner compared to mice of the same genetic origin as well as associated with a lower incidence of cancer and greater longevity [207]. In addition, in sheep and human fibroblasts under prooxidant or antioxidant culture conditions, a positive correlation was found between the levels of DNA damage by OxS and telomere shortening rates, independent of the donor [62]. Likewise, high levels of glucose together with a persistent proinflammatory state results in a higher rate of telomere erosion in aged human fibroblasts [208]. In human fibroblasts under hyperglycemia conditions, TL decreases [209], while caloric restriction in leukocyte and skin samples from rhesus monkeys apparently does not affect telomere length [210]. 
Table 1. MetS and its association with telomere length.

\begin{tabular}{|c|c|c|c|c|}
\hline Population with MetS & Determinations & Objective & Findings & Ref. \\
\hline $\begin{array}{l}7370 \text { patients } \\
\text { (56-73 years old). }\end{array}$ & $\begin{array}{l}\text { Evaluation of the components of the MetS. } \\
\text { The average TL in leukocytes was determined by qPCR. }\end{array}$ & $\begin{array}{l}\text { To investigate gender differences and } \\
\text { their association between TL and MetS. }\end{array}$ & $\begin{array}{c}\text { An increase in the number of MetS components } \\
\text { is associated with shorter TL in the female } \\
\text { population. }\end{array}$ & [211] \\
\hline $\begin{array}{l}2842 \text { patients } \\
\text { (18-65 years old). Follow-up for } 6 \text { years }\end{array}$ & $\begin{array}{l}\text { Evaluation of the components of the MetS. } \\
\text { Basal TL in leukocytes was determined by qPCR. }\end{array}$ & $\begin{array}{l}\text { To associate TL with the metabolic } \\
\text { profile and with the MetS components. }\end{array}$ & $\begin{array}{l}\text { Short TL is associated with higher MetS } \\
\text { component scores, which persist even after } 6 \\
\text { years. }\end{array}$ & [212] \\
\hline $\begin{array}{l}34 \text { male patients } \\
\text { (55-68 years old). }\end{array}$ & $\begin{array}{l}\text { Evaluation of the components of the MetS. } \\
\text { The TL in leukocytes was determined by TRF. } \\
\text { The bilateral ELC was determined by observation of a } \\
\text { deep cut in both ears through the earlobe. }\end{array}$ & $\begin{array}{l}\text { To determine if the ELC is related to } \\
\text { telomeric shortening. }\end{array}$ & $\begin{array}{l}\text { Bilateral ELC is a dermatological indicator } \\
\text { associated with excessive telomere loss in } \\
\text { patients with MetS. }\end{array}$ & [213] \\
\hline $\begin{array}{l}400 \text { women } \\
\text { (18-86 years old). }\end{array}$ & $\begin{array}{l}\text { Evaluation of the components of the MetS. } \\
\text { The TL in leukocytes was determined by qPCR. }\end{array}$ & $\begin{array}{l}\text { To determine the TL and its association } \\
\text { with the metabolic condition in obese } \\
\text { women. }\end{array}$ & $\begin{array}{l}\text { TL is related to MetS and with a greater number } \\
\text { of metabolic abnormalities. }\end{array}$ & [214] \\
\hline $\begin{array}{l}115 \text { subjects } \\
\text { (43-87 years old) }\end{array}$ & $\begin{array}{l}\text { The TL in leukocytes was determined by qPCR. } \\
\text { Test } 2 \mathrm{hPG} \text {. }\end{array}$ & $\begin{array}{l}\text { To establish the relationship between TL } \\
\text { with the different components of MetS, } \\
\text { glucose tolerance, and age. }\end{array}$ & $\begin{array}{l}\text { MetS is associated with shorter telomeres. For its } \\
\text { part, the } 2 \mathrm{hPG} \text { level showed a relationship with } \\
\text { TL regardless of the presence of MetS. }\end{array}$ & [215] \\
\hline $\begin{array}{l}1808 \text { patients } \\
\text { (18-65 years old) } \\
\text { Follow-up for } 6 \text { years }\end{array}$ & $\begin{array}{l}\text { The TL in leukocytes was determined by qPCR. } \\
\text { Anthropometric and biochemical parameters. }\end{array}$ & $\begin{array}{c}\text { To determine whether the components of } \\
\text { the MetS predict TL through time and if } \\
\text { the alterations are parallel to telomeric } \\
\text { attrition. }\end{array}$ & $\begin{array}{l}\text { An increase in waist circumference and glucose, } \\
\text { as well as low HDL-C concentrations, are } \\
\text { associated with shorter TL. }\end{array}$ & [216] \\
\hline
\end{tabular}

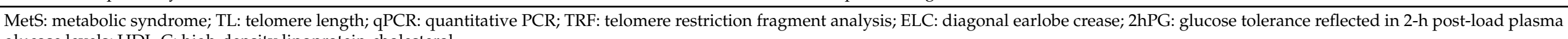
glucose levels; HDL-C: high-density lipoprotein-cholesterol. 


\section{Components of the MetS and Its Relationship with Oxidative Stress and Telomeric Length}

A great variety of studies support that each of the characteristic MetS conditions is related to OxS. For example, it is well established that fat accumulation is associated with OxS at the systemic level, which is mainly due to a decrease in antioxidant enzymes and an increase in fatty acids in adipocytes, due to the activation of the pro-oxidant enzyme nicotinamide adenine dinucleotide phosphate reduced form (NADPH) oxidase [218], which is involved in the formation of ROS [219]. Similarly, it has been observed that adiposity is associated with high plasma levels of lipoperoxidation due to an increase in 8-epi-prostaglandin F2 $\alpha$ (8-epi-PGF2 $\alpha$ ), which leads to the appearance of complications, such as insulin resistance [220]. At the transcriptional level, it also has a negative impact, since it influences the gene expression of the shelterin complex, thereby altering the function of telomeres and triggering the inflammatory process and predisposition to chronic diseases [221].

On the other hand, when there are altered basal blood glucose levels or glucose intolerance, triglycerides (TG) levels and the 8-OHdG adduct are increased [222]. Likewise, an increase in TG, total cholesterol, LDL cholesterol (LDL-C), and MDA are associated with the decrease in the activities of the enzymes, GPx, and SOD in plasma [223].

Regarding the lipid profile, it is known that postprandial hypertriglyceridemia can generate OxS, predisposing to the appearance of chronic cardiometabolic diseases [224], while in animal models, it generates prediabetic neuropathy [225]. Furthermore, it has been shown that low levels of HDL-C are related to an increase in lipoperoxidation and hyperlipidemia in plasma $[223,226]$. It should be noted that this lipoprotein has been conferred anti-inflammatory and antioxidant effects [227].

OxS can modulate blood pressure levels, since ROS directly influence the vascular system through processes such as contraction and dilation or causing hypertension through signal transduction pathways mediated by changes in the cellular redox state [228]. The formation of $\mathrm{O}_{2}{ }^{\bullet-}$ has been pointed out as a primary factor for the development and evolution of hypertension, including insulin resistance [229]. Angiotensin II is a hormone that is also involved in increasing blood pressure, alongside an increase in PGF2 $\alpha$ that exerts antinatriuretic and vasoconstrictor effects with endothelin production, which is involved in the vascular damage caused by OxS $[230,231]$.

Therefore, it can be assumed that OxS is involved in each of the MetS components (Table 2), which in turn are associated with alterations in telomere length (Table 3) predisposing to the deterioration of the metabolic condition of the patients with MetS [134]. 
Table 2. Components of MetS and its association with telomeric length and OxS.

\begin{tabular}{|c|c|c|c|c|c|}
\hline Components of MetS & Population & Determinations & Objective & Findings & Ref. \\
\hline Obesity and OxS & $\begin{array}{l}59 \text { subjects: }(26-57 \text { years old }) \\
\text { CTR }(\mathrm{n}=20) ; \text { Obese }(\mathrm{n}=22) ; \\
\text { Non-obese T2DM }(\mathrm{n}=10) \text { and } \\
\text { Obese-T2DM }(\mathrm{n}=7)\end{array}$ & $\begin{array}{l}\text { TL was determined by qPCR. } \\
\text { Subcutaneous and visceral adipose tissue } \\
\text { from subjects undergoing abdominal } \\
\text { surgery. The size of the adipocytes was } \\
\text { determined by histological staining. } \\
\text { Lipid peroxidation by fluorometry. }\end{array}$ & $\begin{array}{l}\text { To determine the association } \\
\text { between adipocyte size and } \\
\text { adipose tissue TL. }\end{array}$ & $\begin{array}{l}\text { There is hypertrophy in adipocytes of } \\
\text { obese, T2DM, and obese-T2DM subjects } \\
\text { related to shortened TL. TBARS levels } \\
\text { were higher in obese-T2DM and T2DM. }\end{array}$ & [232] \\
\hline $\begin{array}{l}\text { Hypertension, insulin resistance, } \\
\text { and OxS }\end{array}$ & 327 men: (40-89 years old). & $\begin{array}{c}\text { The TL in leukocytes was determined by } \\
\text { TRF. } \\
\text { Determination of HOMA-IR. }\end{array}$ & $\begin{array}{l}\text { To determine the association of } \\
\text { TL with insulin resistance, OxS, } \\
\text { and hypertension. }\end{array}$ & $\begin{array}{c}\text { Hypertension, increased insulin } \\
\text { resistance, OxS, and age are associated } \\
\text { with shorter TL, being more evident in } \\
\text { hypertensive patients, largely due to } \\
\text { insulin resistance. }\end{array}$ & [233] \\
\hline $\begin{array}{l}\text { Hyperglycemia and } \\
\text { OxS }\end{array}$ & $\begin{array}{l}120 \text { subjects: (38-71 years old) } \\
\text { CTR, with IGT, T2DM y T2DM } \\
\text { atherosclerosis. }\end{array}$ & $\begin{array}{l}\text { The TL in leukocytes was determined by } \\
\text { TRF. } \\
\text { Levels of TBARS, PCO, and CRP were } \\
\text { measured by standard methodologies. } \\
\text { IMT was assessed by ultrasonography. }\end{array}$ & $\begin{array}{l}\text { To evaluate if the TL shortening } \\
\text { occurs in the IGT stage and if it is } \\
\text { greater in subjects with T2DM } \\
\text { and atherosclerosis. }\end{array}$ & $\begin{array}{l}\text { TL is lower in patients with T2DM and } \\
\text { atherosclerosis. IGT and TL were } \\
\text { negatively correlated with TBARS, PCO, } \\
\text { and IMT. T2DM and TBARS are } \\
\text { significant determinants of shortening. }\end{array}$ & [234] \\
\hline Hyperglycemia and OxS & $\begin{array}{l}21 \text { subjects: ( } 50-65 \text { years old) } \\
\text { with T2DM. }\end{array}$ & $\begin{array}{l}\text { TL was determined in monocytes by } \\
\text { FISH. } \\
\text { Oxidative damage by flow cytometry. }\end{array}$ & $\begin{array}{c}\text { To establish if telomere } \\
\text { shortening characterises T2DM. }\end{array}$ & $\begin{array}{l}\text { TL in the diabetic group was lower and } \\
\text { was associated with elevated levels of } \\
\text { 8-oxoguanine. }\end{array}$ & [235] \\
\hline Hyperglycemia and OxS & $\begin{array}{c}80 \text { subjects: }(49-56 \text { years old }) \\
\text { T2DM }(\mathrm{n}=40) \\
\text { CTR }(\mathrm{n}=40)\end{array}$ & $\begin{array}{l}\text { Lymphocyte TL was determined by TRF. } \\
\text { Determine MDA plasma levels using } \\
\text { TBARS. }\end{array}$ & $\begin{array}{l}\text { To determine whether telomeric } \\
\text { shortening occurs in T2DM } \\
\text { patients. }\end{array}$ & $\begin{array}{l}\text { TBARS levels showed a negative } \\
\text { correlation with shortened telomeres in } \\
\text { subjects with T2DM. }\end{array}$ & [236] \\
\hline Hyperglycemia and OxS & $\begin{array}{l}621 \text { patients: T2DM }(\mathrm{n}=173) \\
(24-92 \text { years old }) \\
\text { CTR }(\mathrm{n}=448) \\
(18-61 \text { years old })\end{array}$ & $\begin{array}{l}\text { The TL in leukocytes was determined by } \\
\text { qPCR. } \\
\text { TAOS was determined by a photometric } \\
\text { microassay. } \\
\text { The patients were also genotyped for the } \\
\text { UCP2 functional variants - } 866 \mathrm{G}>\mathrm{A} \text { and } \\
\text { A55V. }\end{array}$ & $\begin{array}{l}\text { To determine the association } \\
\text { between TL and T2DM, OxS, and } \\
\text { gene variation in UCP2. }\end{array}$ & $\begin{array}{l}\text { The shorter TL was associated with } \\
\text { T2DM attributed to high OxS. } \\
\text { Carriers of the UCP2 -866A allele have a } \\
\text { shorter TL compared to common } \\
\text { homozygotes. }\end{array}$ & [237] \\
\hline
\end{tabular}

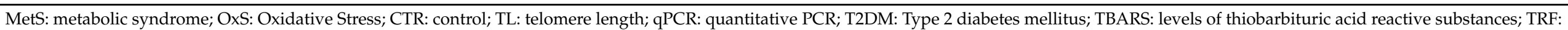

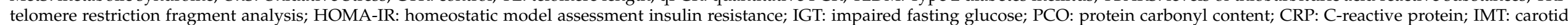
intima-media thickness; FISH: fluorescent in situ-hibridization); MDA: malondialdehyde; TAOS: total antioxidant status; UCP2: a gene involved in the mitochondrial production of ROS. 
Table 3. Components of MetS and its association with telomeric length.

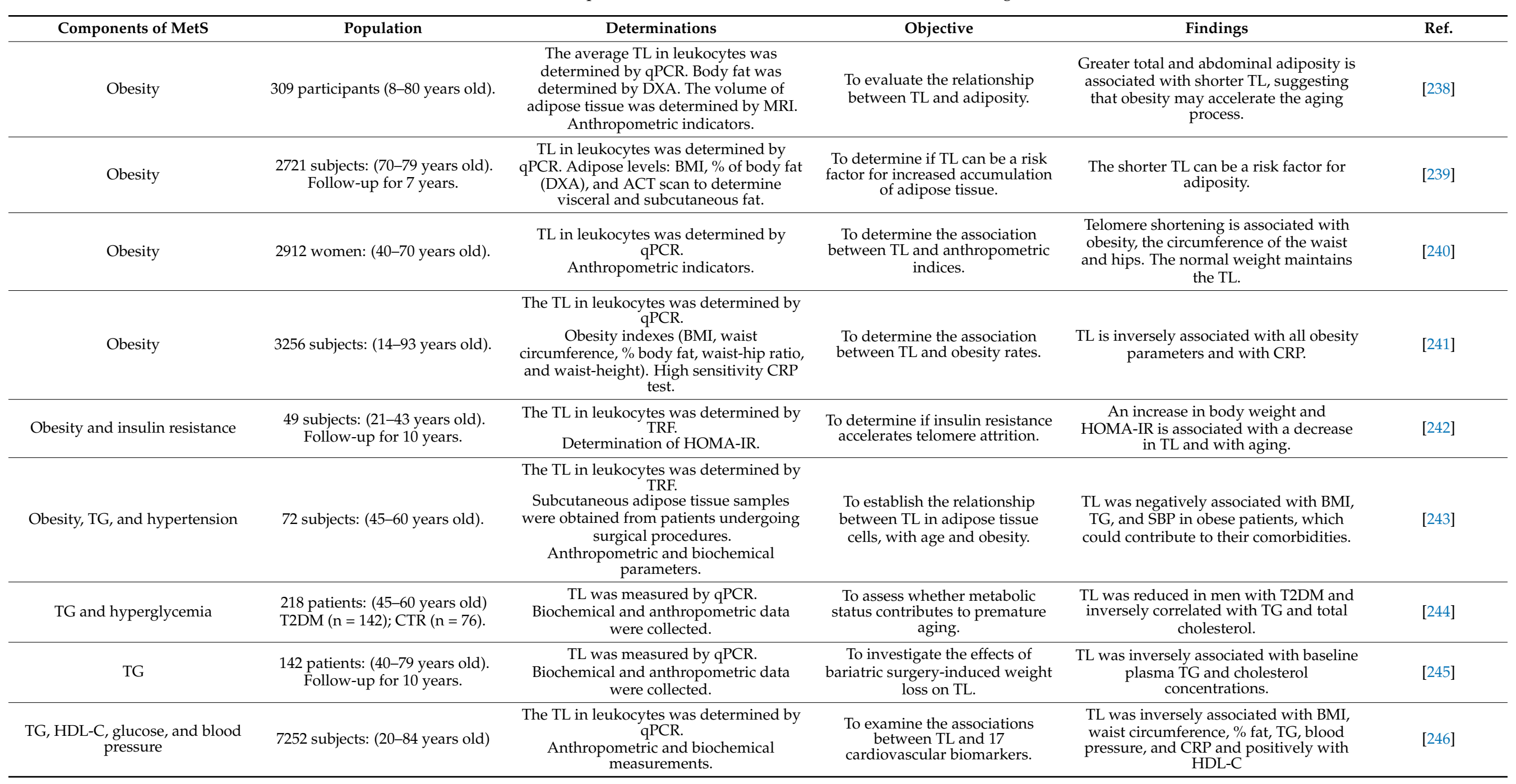


Table 3. Cont.

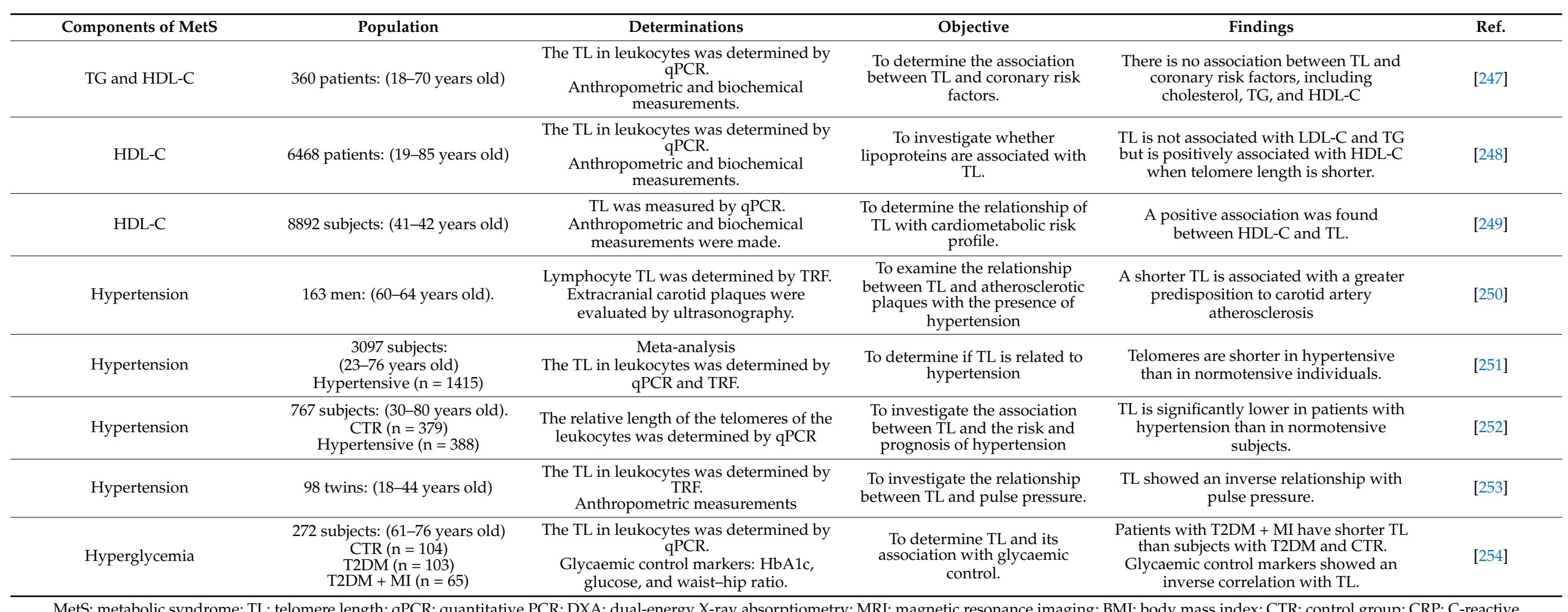

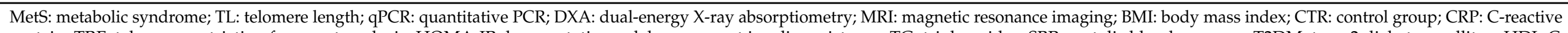

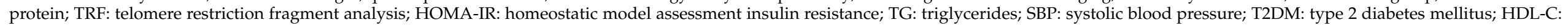

high-density lipoprotein-cholesterol; LDL-C: low-density lipoprotein-cholesterol; MI: myocardial infarction; HbA1c: glycated hemoglobin. 


\section{Telomere Length and Inflammation in the MetS}

Telomere shortening, as mentioned above, is associated with many conditions including MetS, which also presents a low-grade inflammatory state [255]. In other words, it does not cause an injury or loss of the infiltrated tissue [256] that is associated with alterations in the circulating levels of cytokines and acute phase reactants. A vicious cycle appears to be created between the inflammatory process that contributes to telomere dysfunction and aging, while attrition can promote low-grade inflammation [257] and ultimately reflect some type of disability or decrease in life expectancy.

It has been proposed that an increase in body mass index (BMI) stimulates the release of inflammatory mediators such as tumor necrosis factor-alpha (TNF- $\alpha$ ), interleukin 6 (IL-6), Creactive protein (CRP), and fibrinogen. Thus, it is considered that a cumulative inflammatory load due to the combination of high levels of IL-6, TNF- $\alpha$, and CRP is associated with greater probabilities of a short TL in older adults with MetS [241,246,258-262].

A transcription factor that plays a key role in the inflammatory process as well as in the regulation of the catalytic subunit of the telomerase is the nuclear factor-kB (NF-kB) [263]. Given the fact that, in an injury response, NF-kB is activated by pro-inflammatory signaling mediated by TNF- $\alpha$, a robust endogenous ROS generator, via c-Myc inducing rapid translocation of NF-kB, which ultimately leads to the increased expression and activation of the TERT subunit of telomerase [264]. It has also been observed that when telomerase is overexpressed, the non-phosphorylated accumulation of NF-kB-p65 is induced in the nucleus, without affecting its signaling and probably increasing its stability by avoiding the recognition of degradation mechanisms mediated by the ubiquitin/proteasome system. In addition, its accumulation is positively associated with IL-6 gene expression $[265,266]$. It is also known that the expression of RAP1, a component of the shelterin complex, acts as a modulator of the NF-kB [267]. There is evidence that supports the fact that an increase in ROS levels is associated with an increase in the expression of the TNF- $\alpha$ and NF-kB. In addition, the activation of $\mathrm{p} 53$ leads to the induction of NF-kB dependent pro-inflammatory cytokines, which may precipitate the development of T2DM [268].

When an alteration in the homeostasis of pro-inflammatory and anti-inflammatory adipokines occurs, caused by obesity, it can induce insulin resistance and lead to the development of MetS [269]. Some molecules are altered in this syndrome, as they are associated with increased adiposity, as in the case of monocyte chemoattractant protein (MCP-1). On the contrary, other adipokines with anti-inflammatory properties such as adiponectin $(\mathrm{ApN})$ are decreased [270]. The latter is related to inhibition of the expression of TNF- $\alpha$ in adipose tissue and the cells of the immune system such as macrophages [271]. A positive association has even been observed between TL and adiponectin, bringing positive effects against accelerated aging [272].

In aged animals, TERT gene expression is negatively correlated with weight, while TNF- $\alpha$ and MCP-1 have a positive correlation, suggesting that age and weight are factors that impact telomerase expression. This can generate an alteration in the function of telomeres in adipose tissue, thereby predisposing to an inflammatory state and age-related chronic diseases [221].

On the other hand, it is recognised that suppressing the chronic inflammatory process may be a key factor for greater longevity [273] and health. In this regard, the consumption of chayote reduces the concentration of TNF- $\alpha$ and maintains telomerase levels [189,274]. Meanwhile, telomerase activator (TA-65), a natural compound used in traditional Chinese medicine, can lengthen telomeres and reduce levels of inflammation mediated by TNF- $\alpha$ and CRP in patients with MetS $[275,276]$.

\section{Effect of Healthy Lifestyles on Oxidative Stress and the Telomere Length}

The dynamics of telomere length can depend on the type of lifestyle that the person develops. For example, healthy habits include aerobic exercise such as running [277], which causes an increase in the expression of the catalytic subunit of the telomerase hTERT and the protein TPP1 [278]; Tai Chi practice also improves telomerase activity [279], which is 
probably attributable to an increase in the activity of endogenous SOD and GPx enzymes and a reduction of lipoperoxidation during aging [280,281]; and intensive activities such as skiing, badminton, or basketball are related to a much longer TL [282]. It should be noted that the exercise must be personalised, since the effects are variable according to the frequency, duration, type, intensity, and chronological age of the individual [283].

Similarly, nutritional status is another factor that influences telomere length [284]. For example, the long-term supplementation of foods that are rich in omega-3 (n-3) polyunsaturated fatty acids (PUFA) [285], vitamins such as vitamin A [286], B or folate [287], C, E [288], and D [289], carotenoids such as lutein and zeaxanthin [290,291], polyphenols [292], fiber [293], greater adherence to the Mediterranean diet, or a diet rich in vegetables and fruits (whole grains, nuts, tea, coffee, and legumes) or consumption of eggs, fish, seaweed, minerals such as copper, iron, magnesium, and calcium [294-297], delay the shortening of the TL in older adults through glycated hemoglobin (HbA1c) [284,288]. These effects are mainly attributable to the overexpression of endogenous antioxidants that cause a decrease in OxS and mitochondrial dysfunction [298] or they are also attributable to its anti-inflammatory properties [299].

Likewise, some supplements have been used for therapeutic purposes, such as resveratrol, a polyphenolic compound found in grapes, which increases telomerase activity by increasing the expression of the catalytic subunit hTERT in a dose-dependent manner in patients who suffered from myocardial infarction [300] and improved glucose (glycated hemoglobin) and insulin levels in middle-aged subjects with T2DM [301], conferring hypoglycaemic, antioxidant, and anti-inflammatory properties [302]. Similar properties have been attributed to chayote, which maintains telomerase levels associated with an increase in SOD and a decrease in OxS together with a decrease in TNF- $\alpha$ in patients with MetS $[189,274]$. Additionally, in vitro studies have shown that turmeric roots cause an increase in TERT activity, which can have a favorable effect on telomere length [303].

Unhealthy lifestyles include sleep deprivation and its disorders, such as insomnia [304] and obstructive sleep apnea [305], which have considerable adverse effects during aging that are associated with increased lipoperoxidation [306] and with telomeric attrition compared to older adults with longer periods of sleep ( $>7 \mathrm{~h}$ per night) $[307,308]$. A similar effect is observed in psychological stress in terms of OxS and TL, also showing lower telomerase activity [309]. Regarding smoking, there are contradictory results over the TL [310]; however, most studies suggest that there is a shortening of telomeres in smokers [311] associated with lipoperoxidation [312]. In addition, the consumption of sugary carbonated beverages is associated with shorter telomeres [313], even if the consumption starts from the early stages of life and before the development of obesity [314]. Similarly, a higher intake of processed meat or heavy alcohol consumption may result in the reduction of the TL $[315,316]$. Hence, malnutrition with a high intake of fats, sugars, and sodium, along with a low intake of fruits and vegetables, predisposes to constant OxS levels, thereby accelerating the appearance of MetS.

\section{Conclusions}

MetS is characterised by a series of different metabolic abnormalities associated with OxS and decreased antioxidant protection mechanisms. This predisposes to telomere length shortening, which in turn is aggravated by the cumulative effects of its components, such as obesity, hyperglycemia, and hypertension, while dyslipidemia shows a discrepancy in these associations. The difficulty for the correct treatment lies in its multifactorial nature and in the use of drugs that are used simultaneously for long periods and with possible side effects. Therefore, new interventions are necessary, such as promoting healthy lifestyles with physical activity, the use of nutraceuticals, senolytics or inhibitory antisense oligonucleotides. Such interventions delay the telomeric attrition and decrease or suppress the oxidative state, thus helping to respond on time to the control of the different conditions of the MetS to prevent the development of chronic degenerative diseases and improve the living conditions of these people. 
Author Contributions: Writing-original draft preparation, G.G.-G., J.R.-P., T.L.A.-U. and I.A.-S.; writing-review and editing, E.S.-O. and V.M.M.-N. All authors have read and agreed to the published version of the manuscript.

Funding: This work was supported by grants from the General Directorate of Academic Personnel Affairs, National Autonomous University of Mexico (DGAPA-UNAM) (PAPIIT IN215821), and the Secretariat of Science and the Technology and Innovation Project of Mexico City (SECITI) (SECITI/045/2018).

Institutional Review Board Statement: Not applicable.

Informed Consent Statement: Not applicable.

Data Availability Statement: Not applicable.

Acknowledgments: We appreciate the support from the General Directorate of Academic Personnel Affairs, National Autonomous University of Mexico (DGAPA-UNAM) for the scholarship granted to G.G.-G. for postdoctoral stay.

Conflicts of Interest: The authors declare no conflict of interest.

\section{References}

1. Shay, J.W. Telomeres and aging. Curr. Opin. Cell Biol. 2018, 52, 1-7. [CrossRef] [PubMed]

2. Prasad, K.N.; Wu, M.; Bondy, S.C. Telomere shortening during aging: Attenuation by antioxidants and anti-inflammatory agents. Mech. Ageing Dev. 2017, 164, 61-66. [CrossRef] [PubMed]

3. Blackburn, E. Structure and function of telomeres. Nature 1991, 350, 569-573. [CrossRef] [PubMed]

4. Xin, H.; Liu, D.; Songyang, Z. The telosome/shelterin complex and its functions. Genome Biol. 2008, 9, 232. [CrossRef]

5. Shammas, M.A. Telomeres, lifestyle, cancer, and aging. Curr. Opin. Clin. Nutr. Metab. Care 2011, 14, 28-34. [CrossRef] [PubMed]

6. Hernández, F.R.A. Telómeros y telomerasas. Rev. Cubana Investig. Biomed. 1999, 18, 121-129.

7. Rubtsova, M.P.; Vasilkova, D.P.; Malyavko, A.N.; Naraikina, Y.V.; Zvereva, M.I.; Dontsova, O.A. Telomere lengthening and other functions of telomerase. Acta Nat. 2012, 4, 44-61. [CrossRef]

8. Palm, W.; de Lange, T. How shelterin protects mammalian telomeres. Annu. Rev. Genet. 2008, 42, 301-334. [CrossRef]

9. Chen, L.Y.; Redon, S.; Lingner, J. The human CST complex is a terminator of telomerase activity. Nature 2012, 488, 540-544. [CrossRef]

10. Giraud-Panis, M.J.; Pisano, S.; Poulet, A.; Le-Du, M.H.; Gilson, E. Structural identity of telomeric complexes. FEBS Lett. 2010, 584, 3785-3799. [CrossRef] [PubMed]

11. Hernández, F.R.A. El complejo proceso de la duplicación de los telómeros. Rev. Cubana Genet. Comunit. $2015,9,4-13$.

12. van Steensel, B.; De Lange, T. Control of telomere length by the human telomeric protein TRF1. Nature 1997, 385, 740-743. [CrossRef] [PubMed]

13. Bianchi, A.; Smith, S.; Chong, L.; Elias, P.; De Lange, T. TRF1 is a dimer and bends telomeric DNA. EMBO J. 1997, 16, 1785-1794. [CrossRef]

14. Ye, J.Z.; Donigian, J.R.; Van Overbeek, M.; Loayza, D.; Luo, Y.; Krutchinsky, A.N.; Chait, B.T.; De Lange, T. TIN2 Binds TRF1 and TRF2 simultaneously and stabilizes the TRF2 complex on telomeres. J. Biol. Chem. 2004, 279, 47264-47271. [CrossRef]

15. Hanaoka, S.; Nagadoi, A.; Nishimura, Y. Comparison between TRF2 and TRF1 of their telomeric DNA-bound structures and DNA-binding activities. Protein Sci. 2005, 14, 119-130. [CrossRef]

16. Stansel, R.M.; de Lange, T.; Griffith, J.D. T-loop assembly in vitro involves binding of TRF2 near the 3' telomeric overhang. EMBO J. 2001, 20, 5532-5540. [CrossRef] [PubMed]

17. Baumann, P.; Cech, T.R. Pot1, the putative telomere end-binding protein in fission yeast and humans. Science 2001, 292, 1171-1175. [CrossRef]

18. Baumann, P.; Price, C. Pot1 and telomere maintenance. FEBS Lett. 2010, 584, 3779-3784. [CrossRef] [PubMed]

19. Lim, C.J.; Zaug, A.J.; Kim, H.J.; Cech, T.R. Reconstitution of human shelterin complexes reveals unexpected stoichiometry and dual pathways to enhance telomerase processivity. Nat. Commun. 2017, 8, 1075. [CrossRef]

20. Gilson, E.; Gasser, S.M. Repressor activator protein 1 and its ligands: Organising chromatin domains. In Nucleic Acids and Molecular Biology; Eckstein, F., Lilley, D.M.J., Eds.; Springer: Berlin/Heidelberg, Germany, 1995; Volume 9, pp. $308-309$.

21. Takai, K.K.; Kibe, T.; Donigian, J.R.; Frescas, D.; de Lange, T. Telomere protection by TPP1/POT1 requires tethering to TIN2. Mol. Cell 2011, 44, 647-659. [CrossRef] [PubMed]

22. Wang, F.; Podell, E.; Zaug, A.; Yang, Y.; Baciu, P.; Cech, T.R.; Le, M. The POT1-TPP1 telomere complex is a telomerase processivity factor. Nature 2007, 445, 506-510. [CrossRef] [PubMed]

23. Liu, D.; O'Connor, M.; Chan, D.; Laegeler, A.; Qin, J.; Songyang, Z. PTOP interacts with POT1 and regulates its localization to telomeres. Nat. Cell Biol. 2004, 6, 673-680. [CrossRef] [PubMed] 
24. Bisht, K.; Smith, E.M.; Tesmer, V.M.; Nandakumar, J. Structural and functional consequences of a disease mutation in the telomere protein TPP1. Proc. Natl. Acad. Sci. USA 2016, 113, 13021-13026. [CrossRef]

25. Sexton, A.N.; Regalado, S.G.; Lai, C.S.; Cost, G.J.; O’Neil, C.M.; Urnov, F.D.; Gregory, P.D.; Jaenisch, R.; Collins, K.; Hockemeyer, D. Genetic and molecular identification of three human TPP1 functions in telomerase action: Recruitment, activation, and homeostasis set point regulation. Genes Dev. 2014, 28, 1885-1899. [CrossRef]

26. Nandakumar, J.; Bell, C.; Weidenfeld, I.; Zaug, A.; Leinwand, L.; Cech, T. The TEL patch of telomere protein TPP1 mediates telomerase recruitment and processivity. Nature 2012, 492, 285-291. [CrossRef] [PubMed]

27. Adams, M.A.; Dionne, I.; Wellinger, R.J.; Holm, C. The function of DNA polymerase alpha at telomeric G tails is important for telomere homeostasis. Mol. Cell. Biol. 2000, 20, 786-796.

28. Huang, C.; Jia, P.; Chastain, M.; Shiva, O.; Chai, W. The human CTC1/STN1/TEN1 complex regulates telomere maintenance in ALT cancer cells. Exp. Cell Res. 2017, 355, 95-104. [CrossRef]

29. Stewart, J.A.; Wang, F.; Chaiken, M.F.; Kasbek, C.; Chastain, P.D.; Wright, W.E.; Price, C.M. Human CST promotes telomere duplex replication and general replication restart after fork stalling. EMBO J. 2012, 31, 3537-3549. [CrossRef] [PubMed]

30. Grossi, S.; Puglisi, A.; Dmitriev, P.V.; Lopes, M.; Shore, D. Pol12, the B subunit of DNA polymerase alpha, functions in both telomere capping and length regulation. Genes Dev. 2004, 18, 992-1006. [CrossRef]

31. Feng, X.; Hsu, S.; Bhattacharjee, A.; Wang, Y.; Diao, J.; Price, C.M. CTC1-STN1 terminates telomerase while STN1-TEN1 enables C-strand synthesis during telomere replication in colon cancer cells. Nat. Commun. 2018, 9, 2827. [CrossRef]

32. Bryan, C.; Rice, C.; Harkisheimer, M.; Schultz, D.C.; Skordalakes, E. Structure of the human telomeric Stn1-Ten1 capping complex. PLoS ONE 2013, 8, e66756. [CrossRef] [PubMed]

33. Kasbek, C.; Wang, F.; Price, C.M. Human TEN1 maintains telomere integrity and functions in genome-wide replication restart. J. Biol. Chem. 2013, 288, 30139-30150. [CrossRef] [PubMed]

34. de Lange, T. Shelterin: The protein complex that shapes and safeguards human telomeres. Genes Dev. 2005, 19, 2100-2110. [CrossRef]

35. Harley, C.B.; Futcher, A.B.; Greider, C.W. Telomeres shorten during ageing of human fibroblasts. Nature 1990, 345, 458-460. [CrossRef] [PubMed]

36. Wynford-Thomas, D.; Kipling, D. Cancer and the knockout mouse. Nature 1997, 389, 551-552. [CrossRef] [PubMed]

37. von Zglinicki, T. Oxidative stress shortens telomeres. Trends Biochem. Sci. 2002, 27, 339-344. [CrossRef]

38. Blackburn, E.H. Telomere states and cell fates. Nature 2000, 408, 53-56. [CrossRef]

39. Wu, A.; Ichihashi, M.; Ueda, M. Correlation of the expression of human telomerase subunits with telomerase activity in normal skin and skin tumors. Cancer 1999, 86, 2038-2044. [CrossRef]

40. Mitchell, J.R.; Cheng, J.; Collins, K. A box H/ACA small nucleolar RNA-like domain at the human telomerase RNA 3' end. Mol. Cell. Biol. 1999, 19, 567-576. [CrossRef]

41. Yang, J.; Chang, E.; Cherry, A.M.; Bangs, C.D.; Oeii, Y.; Bodnari, A.; Bronsteini, A.; Chiui, C.P.; Herron, G.S. Human endothelial cell life extensión by telomerase expression. J. Biol. Chem. 1999, 271, 21141-21148. [CrossRef]

42. Perez, M.; Dubner, D.; Michelin, S.; Gisone, P.; Carosella, E. Telómeros y reparación de daño genómico su implicancia en patología humana. Medicina (Buenos Aires) 2002, 62, 593-603.

43. Rostamiani, K.; Klauck, S.M.; Heiss, N.; Poustka, A.; Khaleghi, M.; Rosales, R.; Metzenberg, A.B. Novel mutations of the DKC1 gene in individuals affected with dyskeratosis congénita. Blood Cells Mol. Dis. 2010, 44, 88. [CrossRef]

44. Venteicher, A.S.; Abreu, E.B.; Meng, Z.; McCann, K.E.; Terns, R.M.; Veenstra, T.D.; Terns, M.P.; Artandi, S.E. A human telomerase holoenzyme protein required for Cajal body localization and telomere synthesis. Science 2009, 323, 644-648. [CrossRef]

45. Stern, J.L.; Zyner, K.G.; Pickett, H.A.; Cohen, S.B.; Bryan, T.M. Telomerase recruitment requires both TCAB1 and Cajal bodies independently. Mol. Cell. Biol. 2012, 32, 2384-2395. [CrossRef]

46. Wang, Q.; Sawyer, I.; Sung, M.; Sturgill, D.; Shevstsov, S.P.; Pegoraro, G.; Hakim, O.; Baek, S.; Hager, G.L. Cajal bodies are linked to genome conformation. Nat. Commun. 2016, 7, 10966. [CrossRef]

47. Pogacic, V.; Dragon, F.; Filipowicz, W. Human H/ACA small nucleolar RNPs and telomerase share evolutionarily conserved proteins NHP2 and NOP10. Mol. Cell. Biol. 2000, 20, 9028-9040. [CrossRef]

48. Pellizzoni, L.; Baccon, J.; Charroux, B.; Dreyfuss, G. The survival of motor neurons (SMN) protein interacts with the snoRNP proteins fibrillarin and GAR1. Curr. Biol. 2001, 11, 1079-1088. [CrossRef]

49. Vulliamy, T.; Beswick, R.; Kirwan, M.; Marrone, A.; Digweed, M.; Walne, A.; Dokal, I. Mutations in the telomerase component NHP2 cause the premature ageing syndrome dyskeratosis congenita. Proc. Natl. Acad. Sci. USA 2008, 105, 8073-8078. [CrossRef]

50. Venteicher, A.S.; Meng, Z.; Mason, P.J.; Veenstra, T.D.; Artandi, S.E. Identification of ATPases pontin and reptin as telomerase components essential for holoenzyme assembly. Cell 2008, 132, 945-957. [CrossRef]

51. Sekaran, V.G.; Soares, J.; Jarstfer, M.B. Structures of telomerase subunits provide functional insights. Biochim. Biophys. Acta Proteins Proteom 2010, 1804, 1190-1201. [CrossRef]

52. Baek, S.H. When ATPases pontin and reptin met telomerase. Dev. Cell 2008, 14, 459-461. [CrossRef]

53. Harley, C. Telomerase and cancer therapeutics. Nat. Rev. Cancer 2008, 8, 167-179. [CrossRef] [PubMed]

54. Bryan, T.M.; Englezou, A.; Dalla-Pozza, L.; Dunham, M.A.; Reddel, R.R. Evidence for an alternative mechanism for maintaining telomere length in human tumors and tumor-derived cell lines. Nat. Med. 1997, 3, 1271-1274. [CrossRef] 
55. Webb, C.J.; Wu, Y.; Zakian, V.A. DNA repair at telomeres: Keeping the ends intact. Cold Spring Harb. Perspect. Biol. 2013, 5, a012666. [CrossRef]

56. Frenck, R.W.; Blackburn, E.H.; Shannon, K.M. The rate of telomere sequence loss in human leukocytes varies with age. Proc Natl Acad Sci. USA 1998, 95, 5607-5610. [CrossRef]

57. Bree, R.T.; Stenson-Cox, C.; Grealy, M.; Byrnes, L.; Gorman, A.M.; Samali, A. Cellular longevity: Role of apoptosis and replicative senescence. Biogerontology 2002, 3, 195-206. [CrossRef] [PubMed]

58. Kuhlow, D.; Florian, S.; von Figura, G.; Weimer, S.; Schulz, N.; Petzk, K.J.; Zarse, K.; Pfeiffer, A.F.; Rudolph, K.L.; Ristow, M. Telomerase deficiency impairs glucose metabolism and insulin secretion. Aging (Albany N. Y.) 2010, 2, 650-658. [CrossRef] [PubMed]

59. Daubenmier, J.; Lin, J.; Blackburn, E.; Hecht, F.M.; Kristeller, J.; Maninger, N.; Kuwata, M.; Bacchetti, P.; Havel, P.J.; Epel, E. Changes in stress, eating, and metabolic factors are related to changes in telomerase activity in a randomized mindfulness intervention pilot study. Psychoneuroendocrinology 2012, 37, 917-928. [CrossRef]

60. Tristano, A.; Chollet, M.A.; Willson, M.L.; Adjounian, H.; Correa, M.F.; Borges, A. Actividad de la telomerasa en leucocitos de sangre periférica de pacientes con hipertensión arterial esencial. Med. Clin. Barc. 2003, 120, 365-369. [CrossRef]

61. Maeda, T.; Oyama, J.I.; Higuchi, Y.; Arima, T.; Mimori, K.; Makino, N. The correlation between the telomeric parameters and the clinical laboratory data in the patients with brain infarct and metabolic disorders. J. Nutr. Health Aging 2010, 14, $793-797$. [CrossRef]

62. Richter, T.; von Zglinicki, T. A continuous correlation between oxidative stress and telomere shortening in fibroblasts. Exp. Gerontol. 2007, 42, 1039-1042. [CrossRef] [PubMed]

63. Farr, C.; Fantes, J.; Goodfellow, P.; Cooke, H. Functional reintroduction of human telomeres into mammalian cells. Proc. Natl. Acad. Sci. USA 1991, 88, 7006-7010. [CrossRef] [PubMed]

64. Capper, R.; Britt-Compton, B.; Tankimanova, M.; Rowson, J.; Letsolo, B.; Man, S.; Haughton, M.; Baird, D.M. The nature of telomere fusion and a definition of the critical telomere length in human cells. Genes Dev. 2007, 21, 2495-2508. [CrossRef]

65. Di Leonardo, A.; Linke, S.P.; Clarkin, K.; Wahl, G.M. DNA damage triggers a prolonged p53-dependent G1 arrest and long-term induction of Cip1 in normal human fibroblasts. Genes Dev. 1994, 8, 2540-2551. [CrossRef]

66. Bhayadia, R.; Schmidt, B.M.W.; Melk, A.; Hömme, M. Senescence-induced oxidative stress causes endothelial dysfunction. J. Gerontol. Ser. A Biol. Sci. Med. Sci. 2016, 71, 161-169. [CrossRef] [PubMed]

67. Yang, T.L.B.; Song, S.; Johnson, F.B. Contributions of telomere biology to human age-related disease. In Handbook of the Biology of Aging; Kaeberlein, M.R., Martin, G.M., Eds.; Academic Press: Cambridge, MA, USA, 2016; pp. 205-239.

68. Jiang, H.; Ju, Z.; Rudolph, K.L. Telomere shortening and ageing. Z. Gerontol. Geriatr. 2007, 40, 314-324. [CrossRef] [PubMed]

69. Kim, S.H.; Kaminker, P.; Campisi, J. Telomeres, aging and cancer: In search of a happy ending. Oncogene 2002, $21,503-511$. [CrossRef]

70. Passos, J.F.; Saretzki, G.; Ahmed, S.; Nelson, G.; Richter, T.; Peters, H.; Wappler, I.; Birket, M.J.; Harold, G.; Schaeuble, K.; et al. Mitochondrial dysfunction accounts for the stochastic heterogeneity in telomere-dependent senescence. PLoS Biol. 2007, 5, e110. [CrossRef] [PubMed]

71. Childs, B.G.; Baker, D.J.; Kirkland, J.L.; Campisi, J.; Van Deursen, J.M. Senescence and apoptosis: Dueling or complementary cell fates? EMBO Rep. 2014, 15, 1139-1153. [CrossRef] [PubMed]

72. Victorelli, S.; Passos, J.F. Telomeres and cell senescence-Size matters not. EBioMedicine 2017, 21, 14-20. [CrossRef]

73. iedernhofer, L.; Robbins, P. Senotherapeutics for healthy ageing. Nat. Rev. Drug Discov. 2018, 17, 377. [CrossRef] [PubMed]

74. Partridge, L.; Fuentealba, M.; Kennedy, B.K. The quest to slow ageing through drug discovery. Nat. Rev. Drug Discov. 2020, 19, 513-532. [CrossRef] [PubMed]

75. Viel, T.; Chinta, S.; Rane, A.; Chamoli, M.; Buck, H.; Andersen, J. Microdose lithium reduces cellular senescence in human astrocytes-A potential pharmacotherapy for COVID-19? Aging 2020, 12, 10035-10040. [CrossRef] [PubMed]

76. Cardillo, G.M.; De-Paula, V.J.R.; Ikenaga, E.H.; Costa, L.R.; Catanozi, S.; Schaeffer, E.L.; Gattaz, W.F.; Kerr, D.S.; Forlenza, O.V. Chronic lithium treatment increases telomere length in parietal cortex and hippocampus of triple-transgenic alzheimer's disease mice. J. Alzheimers Dis. 2018, 63, 93-101. [CrossRef] [PubMed]

77. Martinsson, L.; Wei, Y.; Xu, D.; Melas, P.A.; Mathé, A.A.; Schalling, M.; Lavebratt, C.; Backlund, L. Long-term lithium treatment in bipolar disorder is associated with longer leukocyte telomeres. Transl. Psychiatry. 2013, 3, e261. [CrossRef]

78. Muñoz-Espín, D.; Serrano, M. Cellular senescence: From physiology to pathology. Nat. Rev. Mol. Cell Biol. 2014, 15, 482-496. [CrossRef] [PubMed]

79. Palmer, A.K.; Tchkonia, T.; LeBrasseur, N.K.; Chini, E.N.; Xu, M.; Kirkland, J.L. Cellular senescence in type 2 diabetes: A therapeutic opportunity. Diabetes 2015, 64, 2289-2298. [CrossRef]

80. Kirkland, J.L.; Tchkonia, T.; Zhu, Y.; Niedernhofer, L.J.; Robbins, P.D. The clinical potential of senolytic drugs. J. Am. Geriatr. Soc. 2017, 65, 2297-2301. [CrossRef]

81. Ogrodnik, M.; Zhu, Y.; Langhi, L.G.; Tchkonia, T.; Krüger, P.; Fielder, E.; Victorello, S.; Ruswhandi, R.A.; Giorgadze, N.; Pirtskhalava, T.; et al. Obesity-induced cellular senescence drives anxiety and impairs neurogenesis. Cell Metab. 2019, 29, 1061-1077. [CrossRef] [PubMed]

82. van Deursen, J.M. The role of senescent cells in ageing. Nature 2014, 509, 439-446. [CrossRef] [PubMed] 
83. Karlseder, J.; Broccoli, D.; Dai, Y.; Hardy, S.; de Lange, T. p53-and ATM-dependent apoptosis induced by telomeres lacking TRF2. Science 1999, 283, 1321-1325. [CrossRef]

84. Multani, A.S.; Ozen, M.; Narayad, S.; Kumar, V.; Chandra, J.; McConkey, D.J.; Newman, R.A.; Pathak, S. Caspase-dependent apoptosis induced by telomere cleavage and TRF2 loss. Neoplasia 2000, 2, 339-345. [CrossRef] [PubMed]

85. Keefe, D.L.; Franco, S.; Liu, L.; Trimarchi, J.; Cao, B.; Weitzen, S.; Agarwal, S.; Blasco, M.A. Telomere length predicts embryo fragmentation after in vitro fertilization in women-Toward a telomere theory of reproductive aging in women. Am. J. Obstet. Gynecol. 2005, 192, 1256-1260. [CrossRef] [PubMed]

86. Keefe, D.L.; Liu, L.; Marquard, K. Telomeres and aging-related meiotic dysfunction in women. Cell. Mol. Life Sci. 2007, 64, 139-143. [CrossRef] [PubMed]

87. Ferlin, A.; Rampazzo, E.; Rocca, M.S.; Keppel, S.; Frigo, A.C.; De Rossi, A.; Foresta, C. In young men sperm telomere length is related to sperm number and parental age. Hum. Reprod. 2017, 28, 3370-3376. [CrossRef]

88. Baccetti, B.; Collodel, G.; Piomboni, P. Apoptosis in human ejaculated sperm cells (notulae seminologicae 9). J. Submicrosc. Cytol. Pathol. 1996, 28, 587-596.

89. Amir, S.; Vakonaki, E.; Tsiminikaki, K.; Tzatzarakis, M.N.; Michopoulou, V.; Flamourakis, M.; Kalliantasi, K.; Karzi, V.; Fragkiadaki, P.; Renieri, E.A.; et al. Sperm telomere length: Diagnostic and prognostic biomarker in male infertility (Review). World Acad. Sci. J. 2019, 1, 259-263. [CrossRef]

90. Koju, N.; Taleb, A.; Zhou, J.; Lv, G.; Yang, J.; Cao, X.; Lei, H.; Ding, Q. Pharmacological strategies to lower crosstalk between nicotinamide adenine dinucleotide phosphate (NADPH) oxidase and mitochondria. Biomed. Pharmacother. 2019, 111, 1478-1498. [CrossRef] [PubMed]

91. Burton, G.J.; Jauniaux, E. Oxidative stress. Best Pract. Res. Clin. Obstet. Gynaecol. 2011, 25, 287-299. [CrossRef] [PubMed]

92. Rosado-Pérez, J.; Aguiñiga-Sánchez, I.; Arista-Ugalde, T.L.; Santiago-Osorio, E.; Mendoza-Núñez, V.M. The biological significance of oxidative stress effects of fruits as natural edible antioxidants. Curr. Pharm. Des. 2018, 24, 4807-4824. [CrossRef] [PubMed]

93. Betteridge, D.J. What is oxidative stress? Metabolism 2000, 49, 3-8. [CrossRef]

94. Thomas, D.D. Oxidative stress. In Encyclopedia of Biophysics; Roberts, G.C.K., Ed.; Springer: Berlin, Germany, 2013 ; pp. 1813-1818.

95. Kehrer, J. The Haber-Weiss reaction and mechanism of toxicity. Toxicology 2000, 149, 43-50. [CrossRef]

96. Lindahl, T.; Barnes, D.E. Repair of endogenous DNA damage. Cold Spring Harb. Symp. Quant. Biol. 2000, 65, 127-134. [CrossRef]

97. Fouquerel, E.; Barnes, R.P.; Uttam, S.; Watkins, S.C.; Bruchez, M.P.; Opresko, P.L. Targeted and persistent 8-oxoguanine base damage at telomeres promotes telomere loss and crisis. Mol. Cell 2019, 75, 117-130. [CrossRef]

98. Urbaniak, S.K.; Boguszewska, K.; Szewczuk, M.; Kaźmierczak-Barańska, J.; Karwowski, B.T. 8-Oxo-7,8-dihydro-2'deoxyguanosine (8-oxodG) and 8-Hydroxy-2'-deoxyguanosine (8-OHdG) as a potential biomarker for gestational diabetes mellitus (GDM) development. Molecules 2020, 25, 202. [CrossRef] [PubMed]

99. Mut-Salud, N.; Álvarez, P.J.; Garrido, J.M.; Carrasco, E.; Aránega, A.; Rodríguez-Serrano, F. Antioxidant intake and antitumor therapy: Toward nutritional recommendations for optimal results. Oxid. Med. Cell. Longev. 2016, 2016, 6719534. [CrossRef] [PubMed]

100. Salehi, B.; Martorell, M.; Arbiser, J.L.; Sureda, A.; Martins, N.; Maurya, P.K.; Sharifi-Rad, M.; Kumar, P.; Sharifi-Rad, J. Antioxidants: Positive or negative actors? Biomolecules 2018, 8, 124. [CrossRef] [PubMed]

101. Osterod, M.; Hollenbach, S.; Hengstler, J.G.; Barnes, D.E.; Lindahl, T.; Epe, B. Age-related and tissue-specific accumulation of oxidative DNA base damage in 7, 8-dihydro-8-oxoguanine-DNA glycosylase (Ogg1) deficient mice. Carcinogenesis 2001, 22, 1459-1463. [CrossRef] [PubMed]

102. Harman, D. Free radical theory of aging. Mutat. Res. 1992, 275, 257-266. [CrossRef]

103. Saretzki, G.; von Zglinicki, T. Replicative aging, telomeres, and oxidative stress. Ann. N. Y. Acad. Sci. 2002, 959, 24-29. [CrossRef] [PubMed]

104. Forman, H.J. Redox signaling: An evolution from free radicals to aging. J. Free Radic. Biol. Med. 2016, 97, 398-407. [CrossRef]

105. Liguori, I.; Russo, G.; Curcio, F.; Bulli, G.; Aran, L.; Della-Morte, D.; Gargiulo, G.; Testa, G.; Cacciatore, F.; Bonaduce, D.; et al. Oxidative stress, aging, and diseases. Clin. Interv. Aging 2018, 13, 757-772. [CrossRef] [PubMed]

106. León, R.M.L.; Cedeño, M.R.; Rivero, M.R.J.; García, P.D.L.; Bordón, G.L. La teoría del estrés oxidativo como causa directa del envejecimiento celular. Medisur 2018, 16, 699-710.

107. Chen, Q.M.; Liu, J.; Merrett, J.B. Apoptosis or senescence-like growth arrest: Influence of cell-cycle position, p53, p21 and bax in $\mathrm{H}_{2} \mathrm{O}_{2}$ response of normal human fibroblasts. Biochem. J. 2000, 347, 543-551. [CrossRef]

108. Holt, S.E.; Glinsky, V.V.; Ivanova, A.B.; Glinsky, G.V. Resistance to apoptosis in human cells conferred by telomerase function and telomere stability. Mol. Carcinog. 1999, 25, 241-248. [CrossRef]

109. Muratori, M.; Tamburrino, L.; Cambi, M.; Olivito, B.; Azzari, C.; Forti, G.; Bald, E. Investigation on the origin of sperm DNA fragmentation: Role of apoptosis, immaturity and oxidative stress. Mol. Med. 2015, 21, 109-122. [CrossRef] [PubMed]

110. Redza-Dutordoir, M.; Averill-Bates, D.A. Activation of apoptosis signalling pathways by reactive oxygen species. Biochim. Biophys. Acta Mol. Cell Res. 2016, 1863, 2977-2992. [CrossRef]

111. Henle, E.S.; Han, Z.; Tang, N.; Rai, P.; Luo, Y.; Linn, S. Sequence-specific DNA cleavage by $\mathrm{Fe}^{2+}$-mediated fenton reactions has possible biological implications. J. Biol. Chem. 1999, 274, 962-971. [CrossRef]

112. Kawanishi, S.; Oikawa, S. Mechanism of telomere shortening by oxidative stress. Ann. N. Y. Acad. Sci. 2004, 1019, $278-284$. [CrossRef] 
113. Von Zglinicki, T.; Martin-Ruiz, C.M.; Saretzki, G. Telomeres, cell senescence and human ageing. Signal. Transduct. 2005, 5, $103-114$. [CrossRef]

114. Raha, S.; Robinson, B.H. Mitochondria, oxygen free radicals, disease and ageing. Trends Biochem. Sci. 2000, 25, 502-508. [CrossRef]

115. Mikhelson, V.M.; Gamaley, I.A. Telomere shortening is a sole mechanism of aging in mammals. Curr. Aging Sci. 2012, 5, 203-208. [CrossRef]

116. Cattan, V.; Mercier, N.; Gardner, J.P.; Regnault, V.; Labat, C.; Mäki-Jouppila, J.; Nzietchueng, R.; Benetos, A.; Kimura, M.; Aviv, A.; et al. Chronic oxidative stress induces a tissue-specific reduction in telomere length in CAST/Ei mice. Free Radic. Biol. Med. 2008, 44, 1592-1598. [CrossRef] [PubMed]

117. Ko, E.; Seo, H.W.; Jung, G. Telomere length and reactive oxygen species levels are positively associated with a high risk of mortality and recurrence in hepatocellular carcinoma. Hepatology 2018, 67, 1378-1391. [CrossRef]

118. Opresko, P.; Fan, J.; Danzy, S.; Wilson, D.M.; Bohr, V.A. Oxidative damage in telomeric DNA disrupts recognition by TRF1 and TRF2. Nucleic Acids Res. 2005, 33, 1230-1239. [CrossRef] [PubMed]

119. Chen, Q.; Fischer, A.; Reagan, J.D.; Yan, L.J.; Ames, B.N. Oxidative DNA damage and senescence of human diploid fibroblast cells. Proc. Natl. Acad. Sci. USA 1995, 92, 4337-4341. [CrossRef]

120. Ahmed, W.; Lingner, J. PRDX1 Counteracts catastrophic telomeric cleavage events that are triggered by DNA repair activities post oxidative damage. Cell Rep. 2020, 33, 108347. [CrossRef] [PubMed]

121. Kuzminov, A. Single-strand interruptions in replicating chromosomes cause double-strand breaks. Proc. Natl. Acad. Sci. USA 2001, 98, 8241-8246. [CrossRef]

122. Ceccaldi, R.; Rondinelli, B.; D'Andrea, A.D. Repair pathway choices and consequences at the double-strand break. Trends Cell Biol. 2016, 26, 52-64. [CrossRef]

123. Farmer, H.; McCabe, N.; Lord, C.J.; Tutt, A.N.; Johnson, D.A.; Richardson, T.B.; Santarosa, M.; Dillon, K.J.; Hickson, I.; Knights, C.; et al. Targeting the DNA repair defect in BRCA mutant cells as a therapeutic strategy. Nature 2005, 434, 917-921. [CrossRef]

124. Mendoza-Núñez, V.M.; Martínez-Maldonado, M.L.; Vivaldo-Martínez, M. What is the onset age of human aging and old age? Int. J. Gerontol. 2016, 10, 56. [CrossRef]

125. WHO. Ageing and Life-Course. Facts about Ageing. Available online: https://www.who.int/ageing/about/facts/en/ (accessed on 7 December 2020).

126. Llanes, B.C. Envejecimiento demográfico y necesidad de desarrollar las competencias profesionales en enfermería geriátrica. Rev. Haban. Cien. Med. 2015, 14, 89-96.

127. Ridout, K.K.; Ridout, S.J.; Goonan, K.; Tyrka, A.R.; Price, L.H. Telomeres and Early Life Stress: Neuroendocrinology and Neurobiology Handbook of Stress Series; Fink, G., Ed.; Academic Press: Cambridge, MA, USA, 2017; pp. 185-193.

128. Brouilette, S.; Singh, R.K.; Thompson, J.R.; Goodall, A.H.; Samani, N.J. White cell telomere length and risk of premature myocardial infarction. Arterioscler. Thromb. Vasc. Biol. 2003, 23, 842-846. [CrossRef] [PubMed]

129. Martin-Ruiz, C.; Dickinson, H.O.; Keys, B.; Rowan, E.; Kenny, R.A.; von Zglinicki, T. Telomere length predicts poststroke mortality, dementia, and cognitive decline. Ann. Neurol. 2006, 60, 174-180. [CrossRef]

130. Valdes, A.M.; Richars, J.B.; Gardner, J.P.; Swaminathan, R.; Kimura, M.; Xiaobin, L.; Aviv, A.; Spector, T.D. Telomere length in leukocytes correlates with bone mineral density and is shirter in women with osteoporosis. Osteoporos. Int. 2007, 18, 1203-1210. [CrossRef] [PubMed]

131. Babizhayev., M.A.; Vishnyakova, K.S.; Yegorov, Y.E. Telomere-dependent senescent phenotype of lens epithelial cells as a biological marker of aging and cataractogenesis: The role of oxidative stress intensity and specific mechanism of phospholipid hydroperoxide toxicity in lens and aqueous. Fundam. Clin. Pharmacol. 2011, 25, 139-162. [CrossRef]

132. Weischer, M.; Bojesen, S.E.; Cawthon, R.M.; Freiberg, J.J.; Tybjærg-Hansen, A.; Nordestgaard, B.G. Short telomere length, myocardial infarction, ischemic heart disease, and early death. Arterioscler. Thromb. Vasc. Biol. 2012, 32, 822-829. [CrossRef]

133. Vera, E.; Blasco, M.A. Beyond average: Potential for measurement of short telomeres. Aging (Albany N. Y.) $2012,4,379-392$. [CrossRef]

134. Kirchner, H.; Shaheen, F.; Kalscheuer, H.; Schmid, S.M.; Oster, H.; Lehnert, H. The Telomeric complex and metabolic disease. Genes 2017, 8, 176. [CrossRef]

135. Zgheib, N.K.; Sleiman, F.; Nasreddine, L.; Nasrallah, M.; Nakhoul, N.; Isma'eel, H.; Tamim, H. Short telomere length is associated with aging, central obesity, poor sleep and hypertension in lebanese individuals. Aging Dis. 2018, 9, 77-89. [CrossRef]

136. Soerensen, M.; Thinggaard, M.; Nygaard, M.; Dato, S.; Tan, Q.; Hjelmborg, J.; Andersen-Ranberg, K.; Stevnsner, T.; Bohr, V.A.; Kimura, M.; et al. Genetic variation in TERT and TERC and human leukocyte telomere length and longevity: A cross-sectional and longitudinal analysis. Aging Cell 2012, 11, 223-227. [CrossRef]

137. Haycock, P.C.; Burgess, S.; Nounu, A.; Zheng, J.; Okoli, G.N.; Bowden, J.; Wade, K.H.; Timpson, N.J.; Evans, D.M.; Willeit, P.; et al. Association between telomere length and risk of cancer and non-neoplastic diseases: A mendelian randomization study. JAMA Oncol. 2017, 3, 636-651. [CrossRef] [PubMed]

138. Sánchez-Valle, V.; Méndez-Sánchez, N. Estrés oxidativo, antioxidantes y enfermedad. Med. Sur 2013, 20, $161-168$.

139. Montpetit, A.J.; Alhareeri, A.A.; Montpetit, M.; Starkweather, A.R.; Elmore, L.W.; Filler, K.; Mohanraj, L.; Burton, C.W.; Menzies, V.S.; Lyon, D.E.; et al. Telomere length: A review of methods for measurement. Nurs. Res. 2014, 63, 289-299. [CrossRef]

140. Richter, T.; Proctor, C. The role of intracellular peroxide levels on the development and maintenance of telomere-dependent senescence. Exp. Gerontol. 2007, 42, 1043-1052. [CrossRef] 
141. Aviv, A.; Valdés, A.; Spector, T. Human telomere biology: Pitfalls of moving from the laboratory to epidemiology. Int. J. Epidemiol. 2006, 35, 1424-1429. [CrossRef] [PubMed]

142. Weng, N. Interplay between telomere length and telomerase in human leukocyte differentiation and aging. J. Leukoc. Biol. 2001, 70, 861-867.

143. Strandberg, T.E.; Saijonmaa, O.; Tilvis, R.S.; Pitkälä, K.H.; Strandberg, A.Y.; Miettinen, T.A.; Fyhrquist, F. Association of telomere length in older men with mortality and midlife body mass index and smoking. J. Gerontol. Ser. A Biol. Sci. Med. Sci. 2011, 66, 815-820. [CrossRef] [PubMed]

144. Liu, B.; Sun, Y.; Xu, G.; Snetselaar, L.G.; Ludewig, G.; Wallace, R.B.; Bao, W. Association between body iron status and leukocyte telomere length, a biomarker of biological aging, in a nationally representative sample of us adults. J. Acad. Nutr. Diet. 2019, 119, 617-625. [CrossRef]

145. Marzetti, E.; Lorenzi, M.; Antocicco, M.; Bonassi, S.; Celi, M.; Mastropaolo, S.; Settanni, S.; Valdiglesias, V.; Landi, F.; Bernabei, R.; et al. Shorter telomeres in peripheral blood mononuclear cells from older persons with sarcopenia: Results from an exploratory study. Front. Aging Neurosci. 2014, 6, 233. [CrossRef]

146. Visala, R.D.; Boyle, G.M.; Parsons, P.G.; Watson, K.; Jones, G.L. Influence of ageing, heat shock treatment and in vivo total antioxidant status on gene-expression profile and protein synthesis in human peripheral lymphocytes. Mech. Ageing Dev. 2003, 124, 55-69. [CrossRef]

147. Mendoza-Núñez, V.M.; Ruiz-Ramos, M.; Sánchez-Rodríguez, M.; Retana-Ugalde, R.; Muñoz-Sánchez, J.L. Aging-related oxidative stress in healthy humans. Tohoku J. Exp. Med. 2007, 213, 261-268. [CrossRef] [PubMed]

148. Huerta, J.M.; González, S.; Fernández, S.; Patterson, A.M.; Lasheras, C. Lipid peroxidation, antioxidant status and survival in institutionalised elderly: A five-year longitudinal study. Free Radic. Res. 2006, 40, 571-578. [CrossRef] [PubMed]

149. Petersen, S.; Saretzki, G.; von Zglinicki, T. Preferential accumulation of single-stranded regions in telomeres of human fibroblasts. Exp. Cell Res. 1998, 239, 152-160. [CrossRef]

150. Kruk, P.A.; Rampino, N.J.; Bohr, V.A. DNA damage and repair in telomeres: Relation to aging. Proc. Indian Natl. Sci. 1995, 92, 258-262. [CrossRef] [PubMed]

151. Fumagalli, M.; Rossiello, F.; Clerici, M.; Barozzi, S.; Cittaro, D.; Kaplunov, J.M.; Bucci, G.; Dobreva, M.; Matti, V.; Beasejour, C.M.; et al. Telomeric DNA damage is irreparable and causes persistent DNA-damage-response activation. Nat. Cell Biol. 2012, 14, 355-365. [CrossRef] [PubMed]

152. Shafirovich, V.; Geacintov, N.E. Removal of oxidatively generated DNA damage by overlapping repair pathways. Free Radic. Biol. Med. 2017, 107, 53-61. [CrossRef] [PubMed]

153. Cadet, J.; Davies, K.J.A. Oxidative DNA damage \& repair: An introduction. Free Radic. Biol. Med. 2017, 107, 2-12.

154. Miller, A.S.; Balakrishnan, L.; Buncher, N.A.; Opresko, P.L.; Bambara, R.A. Telomere proteins POT1, TRF1 and TRF2 augment long-patch base excision repair in vitro. Cell Cycle 2012, 11, 998-1007. [CrossRef] [PubMed]

155. Dianov, G.; Bischoff, C.; Piotrowski, J.; Bohr, V.A. Repair pathways for processing of 8-oxoguanine in DNA by mammalian cell extracts. J. Biol. Chem. 1998, 273, 33811-33816. [CrossRef] [PubMed]

156. Rhee, D.B.; Ghosh, A.; Lu, J.; Bohr, V.A.; Liu, Y. Factors that influence telomeric oxidative base damage and repair by DNA glycosylase OGG1. DNA Repair 2011, 10, 34-44. [CrossRef]

157. Karihtala, P.; Kauppila, S.; Puistola, U.; Jukkola-Vuorinen, A. Absence of the DNA repair enzyme human 8-oxoguanine glycosylase is associated with an aggressive breast cancer phenotype. Br. J. Cancer 2012, 106, 344-347. [CrossRef] [PubMed]

158. Kubo, N.; Morita, M.; Nakashima, Y.; Kitao, H.; Egashira, A.; Saeki, H.; Oki, E.; Kakeji, Y.; Oda, Y.; Maehara, Y. Oxidative DNA damage in human esophageal cancer: Clinicopathological analysis of 8-hydroxydeoxyguanosine and its repair enzyme. Dis. Esophagus 2014, 27, 285-293. [CrossRef]

159. Lansdorp, P.M. Repair of telomeric DNA prior to replicative senescence. Mech. Ageing Dev. 2000, 118, 23-34. [CrossRef]

160. Coluzzi, E.; Colamartino, M.; Cozzi, R.; Leone, S.; Meneghini, C.; O'Callaghan, N.; Sgura, A. Oxidative stress induces persistent telomeric DNA damage responsible for nuclear morphology change in mammalian cells. PLoS ONE 2014, 9, e110963. [CrossRef] [PubMed]

161. Aguado, J.; Sola-Carvajal, A.; Cancila, V.; Revêchon, G.; Ong, P.F.; Jones-Weinert, C.W.; Arzt, E.W.; Lattanzi, G.; Dreesen, O.; Tripodo, C.; et al. Inhibition of DNA damage response at telomeres improves the detrimental phenotypes of Hutchinson-Gilford Progeria Syndrome. Nat. Commun. 2019, 10, 1-11.

162. Cusanelli, E.; Chartrand, P. Telomeric nonconding RNA: Telomeric repeat-containg RNA in telomere biology. Wiley Interdiscip. Rev. RNA 2014, 5, 407-419. [CrossRef] [PubMed]

163. Porro, A.; Feuerhahn, S.; Delafontaine, J.; Riethman, H.; Rougemont, J.; Lingner, J. Functional characterization of the TERRA transcriptome at damaged telomeres. Nat. Commun. 2014, 5, 5379. [CrossRef] [PubMed]

164. Santosh, B.; Varshney, A.; Yadava, P.K. Non-coding RNAs: Biological functions and applications. Cell Biochem. Funct. 2015, 33, 14-22. [CrossRef] [PubMed]

165. Bettin, N.; Oss Pegorar, C.; Cusanelli, E. The emerging roles of TERRA in telomere maintenance and genome stability. Cells 2019, 8, 246. [CrossRef] [PubMed]

166. Rossiello, F.; Aguado, J.; Sepe, S.; Iannello, F.; Nguyen, Q.; Pitchiaya, S.; Carninci, P.; di Fagagna, F.D.A. DNA damage response inhibition at dysfunctional telomeres by modulation of telomeric DNA damage response RNAs. Nat. Commun. 2017, 8 , 13980. [CrossRef] [PubMed] 
167. Genua, M.I.; Miró, B.; Hernández, R.; Martínez, M.; Miró, M.; Pardo, C. Geriatría. In Farmacia Hospitalaria; Bonal, J., DomínguezGil., Gamundi, M.C., Napal, V., Valverde, E., Eds.; Doyma: Madrid, Spain, 2002; pp. 959-992.

168. Domínguez, L.J.; Barbagallo, M. The biology of the metabolic syndrome and aging. Curr. Opin. Clin. Nutr. Metab. Care 2016, 19, 5-11. [CrossRef] [PubMed]

169. Grundy, S.M. Metabolic syndrome pandemic. Arterioscler. Thromb. Vasc. Biol. 2008, 28, 629-636. [CrossRef] [PubMed]

170. Levin, B.E.; Llabre, M.M.; Dong, C.; Elkind, M.S.; Stern, Y.; Rundek, T.; Sacco, R.L.; Wright, C.B. Modeling metabolic syndrome and its association with cognition: The Northern Manhattan study. J. Int. Neuropsychol. Soc. 2014, 20, 951-960. [CrossRef] [PubMed]

171. Rojas, R.; Aguilar-Salinas, C.A.; Jiménez-Corona, A.; Shamah-Levy, T.; Rauda, J.; Ávila-Burgos, L.; Villalpando, S.; Lazcano-Ponce, E. Metabolic syndrome in Mexican adults. Results from the National Health and Nutrition Survey 2006. Salud. Publica Mex. 2010, 52, S11-S18. [CrossRef] [PubMed]

172. Lin, F.; Roiland, R.; Chen, D.G.; Qiu, C. Linking cognition and frailty in middle and old age: Metabolic syndrome matters. Int. J. Geriatr. Psychiatry 2015, 30, 64-71. [CrossRef] [PubMed]

173. Bonomini, F.; Rodella, L.F.; Rezzani, R. Metabolic syndrome, aging and involvement of oxidative stress. Aging Dis. 2015, 6, 109-120. [CrossRef]

174. Hopps, E.; Noto, D.; Caimi, G.; Averna, M.R. A novel component of the metabolic syndrome: The oxidative stress. Nutr. Metab. Cardiovasc. Dis. 2010, 20, 72-77. [CrossRef]

175. Avelar, T.M.T.; Storch, A.S.; Castro, L.A.; Azevedo, G.V.M.M.; Ferraz, L.; Lopes, P.F. Oxidative stress in the pathophysiology of metabolic syndrome: Which mechanisms are involved? J. Bras. Patol. Med. Lab. 2015, 51, 231-239. [CrossRef]

176. Bakhtiari, A.; Hajian-Tilaki, K.; Omidvar, S.; Nasiri Amiri, F. Association of lipid peroxidation and antioxidant status with metabolic syndrome in Iranian healthy elderly women. Biomed. Rep. 2017, 7, 331-336. [CrossRef]

177. Yubero-Serrano, E.M.; Delgado-Lista, J.; Peña-Orihuela, P.; Perez-Martinez, P.; Fuentes, F.; Marin, C.; Tunez, I.; Tinahones, F.J.; Perez-Jimenez, F.; Roche, H.M.; et al. Oxidative stress is associated with the number of components of metabolic syndrome: LIPGENE study. Exp. Mol. Med. 2013, 45, e28. [CrossRef] [PubMed]

178. Carrier, A. Metabolic syndrome and oxidative stress: A complex relationship. Antioxid. Redox Signal. 2017, 26, 429-431. [CrossRef]

179. Busquets-Cortés, C.; Capó, X.; Argelich, E.; Ferrer, M.D.; Mateos, D.; Bouzas, C.; Abbate, M.; Tur, J.A.; Sureda, A.; Pons, A. Effects of millimolar steady-state hydrogen peroxide exposure on inflammatory and redox gene expression in immune cells from humans with metabolic syndrome. Nutrients 2018, 10, 1920. [CrossRef] [PubMed]

180. Abril-Ulloa, V.; Flores-Mateo, G.; Solà-Alberich, R.; Manuel-y-Keenoy, B.; Arija, V. Ferritin levels and risk of metabolic syndrome: Meta-analysis of observational studies. BMC Public Health 2014, 14, 483. [CrossRef] [PubMed]

181. Wang, M.; Zhao, A.; Szeto, I.M.; Wu, W.; Ren, Z.; Li, T.; Feng, H.; Wang, P.; Wang, Y.; Zhang, Y. Association of serum ferritin with metabolic syndrome in eight cities in China. Food Sci. Nutr. 2020, 8, 1406-1414. [CrossRef] [PubMed]

182. Gillum, R.F. Association of serum ferritin and indices of body fat distribution and obesity in Mexican American men-the third national health and nutrition examination survey. Int. J. Obes. Relat. Metab. Disord. 2001, 25, 639-645. [CrossRef]

183. Halle, M.; Konig, D.; Berg, A.; Keul, J.; Baumstark, M.W. Relationship of serum ferritin concentrations with metabolic cardiovascular risk factors in men without evidence for coronary artery disease. Atherosclerosis 1997, 128, 235-240. [CrossRef]

184. Lee, D.H.; Kang, S.K.; Choi, W.J.; Kwak, K.M.; Kang, D.; Lee, S.H.; Lee, J.H. Association between serum ferritin and hypertension according to the working type in Korean men: The fifth Korean national health and nutrition examination survey $2010-2012$. Ann. Occup. Environ. Med. 2018, 30, 40. [CrossRef] [PubMed]

185. Bao, W.; Rong, Y.; Rong, S.; Liu, L. Dietary iron intake, body iron stores, and the risk of type 2 diabetes: A systematic review and meta-analysis. BMC Med. 2012, 10, 119. [CrossRef]

186. Fujita, K.; Nishizawa, H.; Funahashi, T.; Shimomura, I.; Shimabukuro, M. Systemic oxidative stress is associated with visceral fat accumulation and the metabolic syndrome. Circ. J. 2006, 70, 1437-1442. [CrossRef]

187. Sankhla, M.; Sharma, T.K.; Mathur, K.; Rathor, J.S.; Butolia, V.; Gadhok, A.K.; Kaushik, G.G. Relationship of oxidative stress with obesity and its role in obesity induced metabolic syndrome. Clin. Lab. 2012, 58, 385-392. [PubMed]

188. Mattson, M.P. Roles of the lipid peroxidation product 4-hydroxynonenal in obesity, the metabolic syndrome, and associated vascular and neurodegenerative disorders. Exp. Gerontol. 2009, 44, 625-633. [CrossRef]

189. Gavia-García, G.; Rosado-Pérez, J.; Aguiñiga-Sánchez, I.; Santiago-Osorio, E.; Mendoza-Núñez, V.M. Effect of Sechium edule var. nigrum spinosum (Chayote) on telomerase levels and antioxidant capacity in older adults with metabolic syndrome. Antioxidants 2020, 9, 634. [CrossRef]

190. Holvoet, P.; De Keyzer, D.; Jacobs, D.R. Oxidized LDL and the metabolic syndrome. Future Lipidol. 2008, 3, 637-649. [CrossRef] [PubMed]

191. Cai, W.; Uribarri, J.; Zhu, L.; Chen, X.; Swamy, S.; Zhao, Z.; Grosjean, F.; Simonaro, C.; Kuchel, G.A.; Schnaider-Beeri, M.; et al. Oral glycotoxins are a modifiable cause of dementia and the metabolic syndrome in mice and humans. Proc. Natl. Acad. Sci. USA 2014, 111, 4940-4945. [CrossRef] [PubMed]

192. Sharma, P.; Mishra, S.; Ajmera, P.; Mathur, S. Oxidative stress in metabolic syndrome. Indian J. Clin Biochem 2005, 20, 145-149. [CrossRef]

193. Vona, R.; Gambardella, L.; Cittadini, C.; Straface, E.; Pietraforte, D. Biomarkers of oxidative stress in metabolic syndrome and associated diseases. Oxid. Med. Cell. Longev. 2019, 2019, 8267234. [CrossRef] [PubMed] 
194. Ford, E.S.; Mokdad, A.H.; Giles, W.H.; Brown, D.W. The metabolic syndrome and antioxidant concentrations: Findings from the third national health and nutrition examination survey. Diabetes 2003, 52, 2346-2352. [CrossRef] [PubMed]

195. Spanidis, Y.; Mpesios, A.; Stagos, D.; Goutzourelas, N.; Bar-Or, D.; Karapetsa, M.; Zakynthinos, E.; Spandidos, D.A.; Tsatsakis, A.M.; Leon, G.; et al. Assessment of the redox status in patients with metabolic syndrome and type 2 diabetes reveals great variations. Exp. Ther. Med. 2016, 11, 895-903. [CrossRef] [PubMed]

196. Chen, S.J.; Yen, C.H.; Huang, Y.C.; Lee, B.J.; Hsia, S.; Lin, P.T. Relationships between inflammation, adiponectin, and oxidative stress in metabolic syndrome. PLoS ONE 2012, 7, e45693. [CrossRef] [PubMed]

197. Skalicky, J.; Muzakova, V.; Kandar, R.; Meloun, M.; Rousar, T.; Palicka, V. Evaluation of oxidative stress and inflammation in obese adults with metabolic syndrome. Clin. Chem. Lab. Med. 2008, 46, 499-505. [CrossRef]

198. Mahjoub, S.; Masrour-Roudsari, J. Role of oxidative stress in pathogenesis of metabolic syndrome. Caspian J. Intern. Med. 2012, 3, 386-396. [PubMed]

199. Tian, R.; Zhang, L.N.; Zhang, T.T.; Pang, H.Y.; Chen, L.F.; Shen, Z.J.; Liu, Z.; Fang, Q.; Zhang, S.Y. Association between oxidative stress and peripheral leukocyte telomere length in patients with premature coronary artery disease. Med. Sci. Monit. 2017, 23, 4382-4390. [CrossRef] [PubMed]

200. McAninch, D.; Bianco-Miotto, T.; Gatford, K.L.; Leemaqz, S.Y.; Andraweera, P.H.; Garrett, A.; Plummer, M.D.; Dekker, G.A.; Roberts, C.T.; Smithers, L.G.; et al. The metabolic syndrome in pregnancy and its association with child telomere length. Diabetologia 2020, 63, 2140-2149. [CrossRef]

201. Galiè, S.; Canudas, S.; Muralidharan, J.; García-Gavilán, J.; Bulló, M.; Salas-Salvadó, J. Impact of nutrition on telomere health: Systematic review of observational cohort studies and randomized clinical trials. Adv. Nutr. 2020, 11, 576-601. [CrossRef] [PubMed]

202. Rentoukas, E.; Tsarouhas, K.; Kaplanis, I.; Korou, E.; Nikolaou, M.; Marathonitis, G.; Kokkinou, S.; Haliassos, A.; Mamalaki, A.; Kouretas, D.; et al. Connection between telomerase activity in pbmc and markers of inflammation and endothelial dysfunction in patients with metabolic syndrome. PLoS ONE 2012, 7, e35739. [CrossRef] [PubMed]

203. Gorbunova, V.; Seluanov, A.; Pereira-Smith, O.M. Evidence that high telomerase activity may induce a senescent-like growth arrest in human fibroblasts. J. Biol. Chem. 2003, 278, 7692-7698. [CrossRef]

204. Braun, S.; Bitton-Worms, K.; LeRoith, D. The link between the metabolic syndrome and cancer. Int. J. Biol. Sci. 2011, 7, 1003-1015. [CrossRef] [PubMed]

205. Bjørge, T.; Lukanova, A.; Jonsson, H.; Tretli, S.; Ulmer, H.; Manjer, J.; Stocks, T.; Selmer, R.; Nagel, G.; Almquist, M.; et al. Metabolic syndrome and breast cancer in the me-can (metabolic syndrome and cancer) project. Cancer Epidemiol. Biomarkers Prev. 2010, 19, 1737-1745. [CrossRef] [PubMed]

206. Russo, A.; Autelitano, M.; Bisanti, L. Metabolic syndrome and cancer risk. Eur. J. Cancer 2008, 4, 293-297. [CrossRef] [PubMed]

207. Muñoz-Lorente, M.A.; Cano-Martin, A.C.; Blasco, M.A. Mice with hyper-long telomeres show less metabolic aging and longer lifespans. Nat. Commun. 2019, 10, 4723. [CrossRef] [PubMed]

208. Salpea, K.D.; Maubaret, C.G.; Kathagen, A.; Ken-Dror, G.; Gilroy, D.W.; Humphries, S.E. The effect of pro-inflammatory conditioning and/or high glucose on telomere shortening of aging fibroblasts. PLoS ONE 2013, 8, e73756. [CrossRef] [PubMed]

209. Sutanto, S.S.I.; McLennan, S.V.; Keech, A.C.; Twigg, S.M. Shortening of telomere length by metabolic factors in diabetes: Protective effects of fenofibrate. J. Cell Commun. Signal. 2019, 13, 523-530. [CrossRef]

210. Smith, D.L.; Mattison, J.A.; Desmond, R.A.; Gardner, J.P.; Kimura, M.; Roth, G.S.; Ingram, D.K.; Allison, D.V.; Aviv, A. Telomere dynamics in Rhesus Monkeys: No apparent effect of caloric restriction. J. Gerontol. 2011, 66A, 1163-1168. [CrossRef] [PubMed]

211. Cheng, Y.Y.; Kao, T.W.; Chang, Y.W.; Wu-Jung, C.; Peng, T.C.; Wu, L.W.; Yang, H.F.; Chen, W.L. Examining the gender difference in the association between metabolic syndrome and the mean leukocyte telomere length. PLoS ONE 2017, 12, e0180687. [CrossRef] [PubMed]

212. Révész, D.; Milaneschi, Y.; Verhoeven, J.E.; Penninx, B.W. Telomere length as a marker of cellular aging is associated with prevalence and progression of metabolic syndrome. J. Clin. Endocrinol. Metab. 2014, 99, 4607-4615. [CrossRef]

213. Higuchi, Y.; Maeda, T.; Guan, J.Z.; Oyama, J.; Sugano, M.; Makino, N. Diagonal earlobe crease are associated with shorter telomere in male Japanese patients with metabolic syndrome. Circ. J. 2009, 73, 274-279. [CrossRef]

214. Iglesias-Molli, A.E.; Panero, J.; Dos Santos, P.C.; González, C.D.; Vilariño, J.; Sereday, M.; Cerrone, G.E.; Slavutsky, I.; Frechtel, G.D. Metabolically healthy obese women have longer telomere length than obese women with metabolic syndrome. PLoS ONE 2017, 12, e0174945. [CrossRef]

215. Khalangot, M.D.; Krasnienkov, D.S.; Chizhova, V.P.; Korkushko, O.V.; Shatilo, V.B.; Kukharsky, V.M.; Kravchenko, V.I.; Kovtun, V.A.; Guryanov, V.G.; Vaiserman, A.M. Additional impact of glucose tolerance on telomere length in persons with and without metabolic syndrome in the elderly Ukraine population. Front. Endocrinol. 2019, 10, 128. [CrossRef] [PubMed]

216. Révész, D.; Milaneschi, Y.; Verhoeven, J.E.; Lin, J.; Penninx, B.W. Longitudinal associations between metabolic syndrome components and telomere shortening. J. Clin. Endocrinol. Metab. 2015, 100, 3050-3059. [CrossRef] [PubMed]

217. Huzen, J.; Wong, L.S.; van Veldhuisen, D.J.; Samani, N.J.; Zwinderman, A.H.; Codd, V.; Cawthon, R.M.; Benus, G.F.; van der Horst, I.C.; Navis, G.; et al. Telomere length loss due to smoking and metabolic traits. J. Intern. Med. 2014, 275, 155-163. [CrossRef] [PubMed] 
218. Furukawa, S.; Fujita, T.; Shimabukuro, M.; Iwaki, M.; Yamada, Y.; Nakajima, Y.; Nakayama, O.; Makishima, M.; Matsuda, M.; Shimomura, I. Increased oxidative stress in obesity and its impact on metabolic syndrome. J. Clin. Investig. 2017, 114, 1752-1761. [CrossRef]

219. Tarafdar, A.; Pula, G. The role of NADPH oxidases and oxidative stress in neurodegenerative disorders. Int. J. Mol. Sci. 2018, 19, 3824. [CrossRef] [PubMed]

220. Urakawa, H.; Katsuki, A.; Sumida, Y.; Gabazza, E.C.; Murashima, S.; Morioka, K.; Maruyama, N.; Kitagawa, N.; Tanaka, T.; Hori, Y.; et al. Oxidative stress is associated with adiposity and insulin resistance in men. J. Clin. Endocrinol. Metab. 2003, 88, 4673-4676. [CrossRef] [PubMed]

221. Bloom, S.I.; Tuluca, A.; Ives, S.J.; Reynolds, T.H. High-fat diet induced obesity and age influence the telomere shelterin complex and telomerase gene expression in mouse ad-ipose tissue. Physiol. Rep. 2020, 8, e14461. [CrossRef] [PubMed]

222. Al-Aubaidy, H.A.; Jelinek, H.F. Oxidative stress and triglycerides as predictors of subclinical atherosclerosis in prediabetes. Redox Rep. 2014, 19, 87-91. [CrossRef] [PubMed]

223. Yang, R.L.; Shi, Y.H.; Hao, G.; Li, W.; Le, G.W. Increasing oxidative stress with progressive hyperlipidemia in human: Relation between malondialdehyde and atherogenic index. J. Clin. Biochem. Nutr. 2008, 43, 154-158. [CrossRef]

224. Le, N.A. Postprandial triglycerides, oxidative stress, and inflammation. In Triglycerides and Cholesterol; Waisundara, V.Y., Jovandaric, M.Z., Eds.; IntechOpen: Rijeka, Croatia, 2020; pp. 1-13.

225. Lupachyk, S.; Watcho, P.; Hasanova, N.; Julius, U.; Obrosova, I.G. Triglyceride, nonesterified fatty acids, and prediabetic neuropathy: Role for oxidative-nitrosative stress. Free Radic. Biol. Med. 2012, 52, 1255-1263. [CrossRef] [PubMed]

226. Kontush, A.; de Faria, E.C.; Chantepie, S.; Chapman, M.J. A normotriglyceridemic, low HDL-cholesterol phenotype is characterised by elevated oxidative stress and HDL particles with attenuated antioxidative activity. Atherosclerosis 2005, 182, 277-285. [CrossRef] [PubMed]

227. Chen, W.; Gardner, J.P.; Kimura, M.; Brimacombe, M.; Cao, X.; Srinivasan, S.R.; Berenson, G.S.; Aviv, A. Leukocyte telomere length is associated with HDL cholesterol levels: The Bogalusa heart study. Atherosclerosis 2009, 205, 620-625. [CrossRef] [PubMed]

228. Briones, A.M.; Touyz, R.M. Oxidative stress and hypertension: Current concepts. Curr. Hypertens. Rep. 2010, 12, 135-142. [CrossRef] [PubMed]

229. de Champlain, J.; Wu, R.; Girouard, H.; Karas, M.; Midaoui, A.E.; Laplante, M.; Wu, L. Oxidative stress in hypertension. Clin Exp. Hypertens. 2004, 26, 593-601. [CrossRef] [PubMed]

230. Romero, J.C.; Reckelhoff, J.F. Role of angiotensin and oxidative stress in essential hypertension. Hypertension 1999, 34, 943-949. [CrossRef] [PubMed]

231. Du Plooy, C.; Mels, M.C.; Huisman, H.; Kruger, R. The association of endothelin-1 with markers of oxidative stress in a biethnic South African cohort: The SABPA study. Hypertens. Res. 2017, 40, 189-195. [CrossRef]

232. Monickaraj, F.; Gokulakrishnan, K.; Prabu, P.; Sathishkumar, C.; Anjana, R.M.; Rajkumar, J.S.; Mohan, V.; Balasubramanyam, M. Convergence of adipocyte hypertrophy, telomere shortening and hypoadiponectinemia in obese subjects and in patients with type 2 diabetes. Clin. Biochem. 2012, 45, 1432-1438. [CrossRef] [PubMed]

233. Demissie, S.; Levy, D.; Benjamin, E.J.; Cupples, L.A.; Gardner, J.P.; Herbert, A.; Kimura, M.; Larson, M.G.; Meigs, J.B.; Keaney, J.F.; et al. Insulin resistance, oxidative stress, hypertension, and leukocyte telomere length in men from the Framingham Heart Study. Aging Cell 2006, 5, 325-330. [CrossRef]

234. Adaikalakoteswari, A.; Balasubramanyam, M.; Mohan, V. Telomere shortening occurs in Asian Indian type 2 diabetic patients. Diabet. Med. 2005, 22, 1151-1156. [CrossRef]

235. Sampson, M.J.; Winterbone, M.K.; Hughes, J.C.; Dozio, N.; Hughes, D.A. Monocyte telomere shortening and oxidative DNA damage in type 2 diabetes. Diabetes Care 2006, 29, 283-289. [CrossRef]

236. Adaikalakoteswari, A.; Balasubramanyam, M.; Ravikumar, R.; Deepa, R.; Mohan, V. Association of telomere shortening with impaired glucose tolerance and diabetic macroangiopathy. Atherosclerosis 2007, 195, 83-89. [CrossRef]

237. Salpea, K.D.; Talmud, P.J.; Cooper, J.A.; Maubaret, C.G.; Stephens, J.W.; Abelak, K.; Humphries, S.E. Association of telomere length with type 2 diabetes, oxidative stress and UCP2 gene variation. Atherosclerosis 2010, 209, 42-50. [CrossRef]

238. Lee, M.; Martin, H.; Firpo, M.A.; Demerath, E.W. Inverse association between adiposity and telomere length: The fels longitudinal study. Am. J. Hum. Biol. 2011, 23, 100-106. [CrossRef] [PubMed]

239. Njajou, O.T.; Cawthon, R.M.; Blackburn, E.H.; Harris, T.B.; Li, R.; Sanders, J.L.; Newman, A.B.; Nalls, M.; Cummings, S.R.; Hsueh, W.C. Shorter telomeres are associated with obesity and weight gain in the elderly. Int. J. Obes. (Lond.) 2012, 36, 1176-1179. [CrossRef]

240. Cui, Y.; Gao, Y.T.; Cai, Q.; Qu, S.; Cai, H.; Li, H.L.; Wu, J.; Ji, B.T.; Yang, G.; Chow, W.H.; et al. Associations of leukocyte telomere length with body anthropometric indices and weight change in Chinese women. Obesity (Silver Spring) 2013, 21, 2582-2588. [CrossRef]

241. Chen, S.; Yeh, F.; Lin, J.; Matsuguchi, T.; Blackburn, E.; Lee, E.T.; Howard, B.V.; Zhao, J. Short leukocyte telomere length is associated with obesity in American Indians: The strong heart family study. Aging (Albany N. Y.) 2014, 6, 380-389. [CrossRef] [PubMed]

242. Gardner, J.P.; Li, S.; Srinivasan, S.R.; Chen, W.; Kimura, M.; Lu, X.; Berenson, G.S.; Aviv, A. Rise in insulin resistance is associated with escalated telomere attrition. Circulation 2005, 111, 2171-2177. [CrossRef] [PubMed] 
243. Moreno-Navarrete, J.M.; Ortega, F.; Sabater, M.; Ricart, W.; Fernández-Real, J.M. Telomere length of subcutaneous adipose tissue cells is shorter in obese and formerly obese subjects. Int. J. Obes. 2010, 34, 1345-1348. [CrossRef] [PubMed]

244. Harte, A.L.; da Silva, N.F.; Miller, M.A.; Cappuccio, F.P.; Kelly, A.; O’Hare, J.P.; Barnett, A.H.; Al-Daghri, N.M.; Al-Attas, O.; Alokail, M.; et al. Telomere length attrition, a marker of biological senescence, is inversely correlated with triglycerides and cholesterol in South Asian males with type 2 diabetes mellitus. Exp. Diabetes Res. 2012, 2012, 895185. [CrossRef]

245. Laimer, M.; Melmer, A.; Lamina, C.; Raschenberger, J.; Adamovski, P.; Engl, J.; Ress, C.; Tschoner, A.; Gelsinger, C.; Mair, L.; et al. Telomere length increase after weight loss induced by bariatric surgery: Results from a 10 year prospective study. Int. J. Obes. 2016, 40, 773-778. [CrossRef]

246. Rehkopf, D.H.; Needham, B.L.; Lin, J.; Blackburn, E.H.; Zota, A.R.; Wojcicki, J.M.; Epel, E.S. Leukocyte telomere length in relation to 17 biomarkers of cardiovascular disease risk: A cross-sectional study of US adults. PLoS Med. 2016, 13, e1002188. [CrossRef]

247. Neuner, B.; Lenfers, A.; Kelsch, R.; Jäger, K.; Brüggmann, N.; van der Harst, P.; Walter, M. Telomere length is not related to established cardiovascular risk factors but does correlate with red and white blood cell counts in a german blood donor population. PLoS ONE 2015, 7, e0139308. [CrossRef] [PubMed]

248. Chen, Y.F.; Zhou, K.W.; Yang, G.Z.; Chen, C. Association between lipoproteins and telomere length in US adults: Data from the NHANES 1999-2002. Lipids Health Dis. 2019, 18, 80. [CrossRef] [PubMed]

249. Mazidi, M.; Kengne, A.P.; Sahebkar, A.; Banach, M. Telomere length is associated with cardiometabolic factors in US adults. Angiology 2017, 69, 164-169. [CrossRef]

250. Benetos, A.; Gardner, J.P.; Zureik, M.; Labat, C.; Xiaobin, L.; Adamopoulos, C.; Temmar, M.; Bean, K.E.; Thomas, F.; Aviv, A. Short telomeres are associated with increased carotid atherosclerosis in hypertensive subjects. Hypertension 2004, 43, 182-185. [CrossRef]

251. Tellechea, M.L.; Pirola, C.J. The impact of hypertension on leukocyte telomere length: A systematic review and meta-analysis of human studies. J. Hum. Hypertens. 2017, 31, 99-105. [CrossRef] [PubMed]

252. Yang, Z.; Huang, X.; Jiang, H.; Zhang, Y.; Liu, H.; Qin, C.; Eisner, G.M.; Jose, P.; Rudolph, L.; Ju, Z. Short telomeres and prognosis of hypertension in a Chinese population. Hypertension 2009, 53, 639-645. [CrossRef]

253. Jeanclos, E.; Schork, N.J.; Kyvik, K.O.; Kimura, M.; Skurnick, J.H.; Aviv, A. Telomere length inversely correlates with pulse pressure and is highly familial. Hypertension 2000, 36, 195-200. [CrossRef]

254. Olivieri, F.; Lorenzi, M.; Antonicelli, R.; Testa, R.; Sirolla, C.; Cardelli, M.; Mariotti, S.; Marchegianif, F.; Marra, M.; Spazzafumoe, L.; et al. Leukocyte telomere shortening in elderly Type 2 DM patients with previous myocardial infarction. Atherosclerosis 2009, 206, 558-593. [CrossRef]

255. Monteiro, R.; Azevedo, I. Chronic inflammation in obesity and the metabolic syndrome. Med. Inflamm. 2010, $2010,289645$. [CrossRef]

256. León-Pedroza, J.I.; González-Tapia, L.A.; del Olmo-Gil, E.; Castellanos-Rodríguez, D.; Escobedo, G.; González-Chávez, A. Inflamación sistémica de grado bajo y su relación con el desarrollo de enfermedades metabólicas: De la evidencia molecular a la aplicación clínica. Cir. Cir. 2015, 83, 543-551. [CrossRef] [PubMed]

257. Squassina, A.; Pisanu, C.; Vanni, R. Mood disorders, accelerated aging, and inflammation: Is the link hidden in telomeres? Cells 2019, 8, 52. [CrossRef]

258. Ramírez, A.M.M.; Sánchez, R.C.; Pérez, D.A.; Millán, B.E. Evaluación del efecto de la ingesta de una alta carga de ácidos grasos saturados sobre los niveles séricos de la proteína $C$ reactiva, alfa1-antitripsina, fibrinógeno y alfa1-glicoproteína ácida en mujeres obesas. Nutr. Hosp. 2010, 25, 72-79.

259. O'Donovan, A.; Pantell, M.S.; Puterman, E.; Dhabhar, F.S.; Blackburn, E.H.; Yaffe, K.; Cawthon, R.M.; Opresko, P.L.; Hsueh, W.C.; Satterfield, S.; et al. Health aging and body composition study. Cumulative inflammatory load is associated with short leukocyte telomere length in the health, aging and body composition study. PLoS ONE 2011, 6, e19687. [CrossRef] [PubMed]

260. Rode, L.; Nordestgaard, B.G.; Weischer, M.; Bojesen, S.E. Increased body mass index, elevated C-reactive protein, and short telomere length. J. Clin. Endocrinol. Metab. 2014, 99, E1671-E1675. [CrossRef]

261. Ebron, K.; Andersen, C.J.; Aguilar, D.; Blesso, C.N.; Barona, J.; Dugan, C.E.; Jones, J.L.; Al-Sarraj, T.; Fernandez, M.L. A Larger body mass index is associated with increased atherogenic dyslipidemia, insulin resistance, and low-grade inflammation in individuals with metabolic syndrome. Metab. Syndr. Relat. Disord. 2015, 13, 458-464. [CrossRef]

262. Ellulu, M.S.; Patimah, I.; Khaza'ai, H.; Rahmat, A.; Abed, Y. Obesity and inflammation: The linking mechanism and the complications. Arch. Med. Sci. 2017, 13, 851-863. [CrossRef]

263. Yin, L.; Hubbard, A.K.; Giardina, C. NF-kB regulates transcription of the mouse telomerase catalytic subunit. J. Biol. Chem. 2000, 275, 36671-36675. [CrossRef]

264. Wang, J.C.; Bennett, M.R. Nuclear Factor-kB-mediated regulation of telomerase. The myc link. Arterioscler. Thromb. Vasc. Biol. 2010, 30, 2327-2328. [CrossRef] [PubMed]

265. Mattiussi, M.; Tilman, G.; Lenglez, S.; Decottignies, A. Human telomerase represses ROS-dependent cellular responses to tumor necrosis factor- $\alpha$ without affecting NF- $\mathrm{kB}$ activation. Cell Signal. 2012, 24, 708-717. [CrossRef]

266. Geng, H.; Wittwer, T.; Dittrich-Breiholz, O.; Kracht, M.; Schmitz, M.L. Phosphorylation of NF-kappaB p65 at Ser468 controls its COMMD1-dependent ubiquitination and target gene-specific proteasomal elimination. EMBO Rep. 2009, 10, 381-386. [CrossRef] 
267. Teo, H.; Ghosh, S.; Luesch, H.; Ghosh, A.; Wong, E.T.; Malik, N.; Orth, A.; de Jesus, P.; Perry, A.S.; Oliver, J.D.; et al. Telomereindependent Rap1 is an IKK adaptor and regulates NF-kappaB-dependent gene expression. Nat. Cell Biol. 2010, 12, 758-767. [CrossRef]

268. Minamino, T.; Orimo, M.; Shimizu, I.; Kunieda, T.; Yokoyama, M.; Ito, T.; Nojima, A.; Nabetani, A.; Oike, Y.; Matsubara, H.; et al. A crucial role for adipose tissue p53 in the regulation of insulin resistance. Nat. Med. 2009, 15, 1082-1087. [CrossRef]

269. Sánchez, N.J.C.; López, Z.D.F.; Pinzón, D.O.A.; Sepúlveda, A.J.C. Adipocinas y síndrome metabólico: Múltiples facetas de un proceso fisiopatológico complejo. Rev. Colom. Cardiol. 2010, 17, 167-176. [CrossRef]

270. Maury, E.; Brichard, S.M. Adipokine dysregulation, adipose tissue inflammation and metabolic syndrome. Mol. Cell. Endocrinol. 2010, 314, 1-16. [CrossRef] [PubMed]

271. Villarreal-Molina, M.T.; Antuna-Puente, B. Adiponectin: Anti-inflammatory and cardioprotective effects. Biochimie 2012, 94, 2143-2149. [CrossRef] [PubMed]

272. Al-Attas, O.S.; Al-Daghri, N.M.; Alokail, M.S.; Alfadda, A.; Bamakhramah, A.; Sabico, S.; Pritlove, D.; Harte, A.; Tripathi, G.; McTernan, P.G.; et al. Adiposity and insulin resistance correlate with telomere length in middle-aged Arabs: The influence of circulating adiponectin. Eur. J. Endocrinol. 2010, 163, 601-607. [CrossRef] [PubMed]

273. Arai, Y.; Martin-Ruiz, C.M.; Takayama, M.; Abe, Y.; Takebayashi, T.; Koyasu, S.; Syematsu, M.; Hirose, N.; von Zglinicki, T. Inflammation, but not telomere length, predicts successful ageing at extreme old age: A longitudinal study of semi-supercentenarians. EBioMedicine 2015, 2, 1549-1558. [CrossRef] [PubMed]

274. Rosado-Pérez, J.; Aguiñiga-Sánchez, I.; Santiago-Osorio, E.; Mendoza-Núñez, V.M. Effect of Sechium edule var. nigrum spinosum (chayote) on oxidative stress and pro-inflammatory markers in older adults with metabolic syndrome: An exploratory study. Antioxidants 2019, 8, 146. [CrossRef] [PubMed]

275. Salvador, L.; Singaravelu, G.; Harley, C.B.; Flom, P.; Suram, A.; Raffaele, J.M. A natural product telomerase activator lengthens telomeres in humans: A randomized, double blind, and placebo controlled study. Rejuvenation Res. 2016, 19, 478-484. [CrossRef] [PubMed]

276. Fernandez, M.L.; Thomas, M.S.; Lemos, B.S.; DiMarco, D.M.; Missimer, A.; Melough, M.; Chun, O.K.; Murillo, A.G.; Alyousef, H.M.; Medina-Vera, I. TA-65, A Telomerase activator improves cardiovascular markers in patients with metabolic syndrome. Curr. Pharm. Des. 2018, 24, 1905-1911. [CrossRef]

277. Loprinzi, P.D.; Sng, E. Mode-specific physical activity and leukocyte telomere length among US adults: Implications of running on cellular aging. Prev. Med. Rep. 2016, 85, 17-19. [CrossRef]

278. Denham, J.; O’Brien, B.J.; Prestes, P.R.; Brown, N.J.; Charchar, F.J. Increased expression of telomere-regulating genes in endurance athletes with long leukocyte telomeres. J. Appl. Physiol. 2016, 120, 148. [CrossRef]

279. Gong, Y.; Tian, G.; Xue, H.; Zhang, X.; Zhao, Y.; Cheng, G. Higher adherence to the 'vegetable-rich' dietary pattern is related to longer telomere length in women. Clin. Nutr. 2018, 37, 1232-1237. [CrossRef]

280. Rosado-Pérez, J.; Santiago-Osorio, E.; Ortiz, R.; Mendoza-Núñez, V.M. Tai Chi diminishes oxidative stress in Mexican older adults. J. Nutr. Health Aging 2012, 16, 642-646. [CrossRef]

281. Goon, J.A.; Aini, A.N.; Musalmah, M.; Anum, M.Y.; Nazaimoon, W.W.; Ngah, W.W. Effect of Tai Chi exercise on DNA damage, antioxidant enzymes, and oxidative stress in middle-age adults. J. Phys. Act. Health 2009, 6, 43-54. [CrossRef] [PubMed]

282. Saßenroth, D.; Meyer, A.; Salewsky, B.; Kroh, M.; Norman, K.; Steinhagen-Thiessen, E.; Demuth, I. Sports and exercise at different ages and leukocyte telomere length in later life-data from the Berlin Aging Study II (BASE-II). PLoS ONE 2015, 10, e0142131. [CrossRef] [PubMed]

283. Sallam, N.; Laher, I. Exercise modulates oxidative stress and inflammation in aging and cardiovascular diseases. Oxid. Med. Cell. Longev. 2016, 2016, 7239639. [CrossRef] [PubMed]

284. Tsoukalas, D.; Fragkiadaki, P.; Docea, A.O.; Alegakis, A.K.; Sarandi, E.; Vakonaki, E.; Salataj, E.; Kouvidi, E.; Nikitovic, D.; Kovatsi, L.; et al. Association of nutraceutical supplements with longer telomere length. Int J. Mol. Med. 2019, 44, 218-226. [CrossRef] [PubMed]

285. Freitas-Simoes, T.M.; Cofán, M.; Blasco, M.A.; Soberón, N.; Foronda, M.; Serra-Mir, M.; Roth, I.; Valls-Pedret, C.; Doménech, M.; Ponferrada-Ariza, E.; et al. Walnut consumption for two years and leukocyte telomere attrition in mediterranean elders: Results of a randomized controlled trial. Nutrients 2018, 10, 1907. [CrossRef]

286. Mazidi, M.; Kengne, A.P.; Cheskin, L.J.; Banach, M. Serum lipophilic antioxidants levels are associated with leucocyte telomere length among US adults. Lipids Health Dis. 2018, 17, 1-6. [CrossRef]

287. Ligi, P.; Cattaneo, M.; D’Angelo, A.; Sampietro, F.; Fermo, I.; Razzari, C.; Fontana, G.; Eugene, N.; Jacques, P.F.; Selhub, J. Telomere length in peripheral blood mononuclear cells is associated with folate status in men. J. Nutr. 2009, 139, $1273-1278$.

288. Xu, Q.; Parks, C.G.; DeRoo, L.A.; Cawthon, R.M.; Sandler, D.P.; Chen, H. Multivitamin use and telomere length in women. Am. J. Clin. Nutr. 2009, 89, 1857-1863. [CrossRef] [PubMed]

289. Zarei, M.; Zarezadeh, M.; Kalajahi, F.H. The relationship between vitamin D and telomere/telomerase: A comprehensive review. J. Fraility Aging 2021, 10, $2-9$.

290. Sen, A.; Marsche, G.; Freudenberger, P.; Schallert, M.; Toeglhofer, A.M.; Nagl, C.; Schmidt, R.; Launer, L.J.; Schmidt, H. Association between higher plasma lutein, zeaxanthin, and vitamin C concentrations and longer telomere length: Results of the Austrian stroke prevention study. J. Am. Geriatr. Soc. 2014, 62, 222-229. [CrossRef] 
291. Maleki, M.; Khelghati, N.; Alemi, F.; Bazdar, M.; Asemi, Z.; Majidinia, M.; Sadeghpoor, A.; Mahmoodpoor, A.; Jadidi-Niaragh, F.; Targhazeh, N.; et al. Stabilization of telomere by the antioxidant property of polyphenols: Anti-aging potential. J. Life Sci. 2020, 259, 118341. [CrossRef] [PubMed]

292. Tucker, L.A. Dietary fiber and telomere length in 5674 U.S. adults: An NHANES study of biological aging. Nutrients 2018, 10, 400. [CrossRef] [PubMed]

293. Crous-Bou, M.; Fung, T.T.; Prescott, J.; Julin, B.; Du, M.; Sun, Q.; Rexrode, K.M.; Hu, F.B.; De Vivo, I. Mediterranean diet and telomere length in nurses' health study: Population based cohort study. BMJ 2014, 349, g6674. [CrossRef]

294. Zhou, M.; Zhu, L.; Cui, X.; Feng, L.; Zhao, X.; He, S.; Ping, F.; Li, W.; Li, Y. Influence of diet on leukocyte telomere length, markers of inflammation and oxidative stress in individuals with varied glucose tolerance: A Chinese population study. Nutr. J. 2015, 15, 1-10. [CrossRef] [PubMed]

295. Liu, J.J.; Crous-Bou, M.; Giovannucci, E.; De Vivo, I. Coffee consumption is positively associated with longer leukocyte telomere length in the nurses' health study. J. Nutr. 2016, 146, 1373-1378. [CrossRef] [PubMed]

296. Mazidi, M.; Kengne, A.P.; Banach, M. Mineral and vitamin consumption and telomere length among adults in the United States. Pol. Arch. Intern. Med. 2017, 127, 87-90.

297. Lee, J.Y.; Shin, C.; Baik, I. Longitudinal associations between micronutrient consumption and leukocyte telomere length. J. Hum. Nutr. Diet. 2017, 30, 236-243. [CrossRef] [PubMed]

298. Kiecolt-Glaser, J.K.; Epel, E.S.; Belury, M.A.; Andridge, R.; Lin, J.; Glaser, R.; Malarkey, W.B.; Hwang, B.S.; Blackburn, E. Omega-3 fatty acids, oxidative stress, and leukocyte telomere length: A randomized controlled trial. Brain Behav. Immun. 2013, $28,16-24$. [CrossRef] [PubMed]

299. Oppedisano, F.; Macrì, R.; Gliozzi, M.; Musolino, V.; Carresi, C.; Maiuolo, J.; Bosco, F.; Nucera, S.; Zito, C.M.; Guarnieri, L.; et al. The anti-inflammatory and antioxidant properties of n-3 PUFAs: Their role in cardiovascular protection. Biomedicines 2020, 8, 306. [CrossRef] [PubMed]

300. Gutlapalli, S.D.; Kondapaneni, V.; Toulassi, I.A.; Poudel, S.; Zeb, M.; Choudhari, J.; Cancarevic, I. The effects of resveratrol on telomeres and post myocardial infarction remodeling. Cureus 2020, 12, e11482.

301. García-Martínez, B.I.; Ruiz-Ramos, M.; Pedraza-Chaverri, J.; Santiago-Osorio, E.; Mendoza-Núñez, V.M. Hypoglycemic effect of resveratrol: A systematic review and meta-analysis. Antioxidants 2021, 10, 69. [CrossRef] [PubMed]

302. Malhotra, A.; Bath, S.; Elbarbry, F. An organ system approach to explore the antioxidative, anti-inflammatory, and cytoprotective actions of resveratrol. Oxid. Med. Cell. Longev. 2015, 2015, 803971. [CrossRef] [PubMed]

303. Pan, M.H.; Wu, J.C.; Ho, C.T.; Badmaev, V. Effects of water extract of Curcuma longa (L.) roots on immunity and telomerase function. J. Complement. Integr. Med. 2017, 14. [CrossRef]

304. Carroll, J.E.; Esquivel, S.; Goldberg, A.; Seeman, T.E.; Effros, R.B.; Dock, J.; Olmstead, R.; Breen, E.C.; Irwin, M.R. Insomnia and telomere length in older adults. Sleep 2016, 39, 559-564. [CrossRef]

305. Kim, K.S.; Kwak, J.W.; Lim, S.J.; Park, Y.K.; Yang, H.S.; Kim, H.J. Oxidative stress-induced telomere length shortening of circulating leukocyte in patients with obstructive sleep apnea. Aging Dis. 2016, 7, 604-613. [CrossRef] [PubMed]

306. Barcelo, A.; Miralles, C.; Barbe, F.; Vila, M.; Pons, S.; Agusti, A.G. Abnormal lipid peroxidation in patients with sleep apnoea. Eur. Respir. J. 2000, 16, 644-647. [CrossRef] [PubMed]

307. Cribbet, M.R.; Carlisle, M.; Cawthon, R.M.; Uchino, B.N.; Williams, P.G.; Smith, T.W.; Gunn, H.E.; Light, K.C. Cellular aging and restorative processes: Subjective sleep quality and duration moderate the association between age and telomere length in a sample of middle-aged and older adults. Sleep 2014, 37, 65-70. [CrossRef] [PubMed]

308. Tempaku, P.F.; Mazzotti, D.R.; Tufik, S. Telomere length as a marker of sleep loss and sleep disturbances: A potential link between sleep and cellular senescence. Sleep Med. 2015, 16, 559-563. [CrossRef] [PubMed]

309. Epel, E.S.; Blackburn, E.H.; Lin, J.; Dhabhar, F.S.; Adler, N.E.; Morrow, J.D.; Cawthon, R.M. Accelerated telomere shortening in response to life stress. Proc. Natl. Acad. Sci. USA 2004, 101, 17312-17315. [CrossRef]

310. Marcon, F.; Siniscalchi, E.; Andreoli, C.; Allione, A.; Fiorito, G.; Medda, E.; Crebelli, R. Telomerase activity, telomere length and hTERT DNA methylation in peripheral blood mononuclear cells from monozygotic twins with discordant smoking habits. Environ. Mol. Mutagen. 2017, 58, 551-559. [CrossRef] [PubMed]

311. Astuti, Y.; Wardhana, A.; Watkins, J.; Wulaningsih, W. Cigarette smoking and telomere length: A systematic review of 84 studies and meta-analysis. Environ. Res. 2017, 158, 480-489. [CrossRef]

312. Ozguner, F.; Koyu, A.; Cesur, G. Active smoking causes oxidative stress and decreases blood melatonin levels. Toxicol. Ind. Health 2005, 21, 21-26. [CrossRef] [PubMed]

313. Leung, C.W.; Laraia, B.A.; Needham, B.L.; Rehkopf, D.H.; Adler, N.E.; Lin, J.; Blackburn, E.H.; Epel, E.S. Soda and cell aging: Associations between sugar-sweetened beverage consumption and leukocyte telomere length in healthy adults from the National health and nutrition examination surveys. Am. J. Public Health 2014, 104, 2425-2431. [CrossRef]

314. Wojcicki, J.M.; Medrano, R.; Lin, J.; Epel, E. Increased cellular aging by 3 years of age in latino, preschool children who consume more sugar-sweetened beverages: A pilot study. Child. Obes. 2018, 14, 3149-3157. [CrossRef] [PubMed]

315. Nettleton, J.A.; Diez-Roux, A.; Jenny, N.S.; Fitzpatrick, A.L.; Jacobs, D.R. Dietary patterns, food groups, and telomere length in the multi-ethnic study of atherosclerosis (MESA). Am. J. Clin. Nutr. 2008, 88, 1405-1412. [CrossRef] [PubMed]

316. Dixit, S.; Whooley, M.A.; Vittinghoff, E.; Roberts, J.D.; Heckbert, S.R.; Fitzpatrick, A.L.; Lin, J.; Leung, C.; Mukamal, K.J.; Marcus, G.M. Alcohol consumption and leukocyte telomere length. Sci. Rep. 2019, 9, 1404. [CrossRef] [PubMed] 